Article

\title{
Site Amplification Analysis of Dushanbe City Area, Tajikistan to Support Seismic Microzonation
}

\author{
Farkhod Hakimov ${ }^{1,2,3, *(\mathbb{D})}$, Gisela Domej ${ }^{4} \mathbb{D}$, Anatoly Ischuk ${ }^{1}$, Klaus Reicherter ${ }^{2} \mathbb{D}$, Lena Cauchie ${ }^{3}$ \\ and Hans-Balder Havenith ${ }^{3}$ (D)
}

1 Seismic Hazard Assessment Department, Academy of Sciences, Institute of Geology, Earthquake Engineering and Seismology, Aini Street 265, Dushanbe 734060, Tajikistan; anatoly.ischuk@gmail.com

2 Neotectonics and Natural Hazards, RWTH Aachen University, Lochnerstraße 4-20, 52056 Aachen, Germany; k.reicherter@nug.rwth-aachen.de

3 Geology Department, University of Liège, Allée du 6 Août, 14/B18, 4000 Liège, Belgium; lena.cauchie@uliege.be (L.C.); hb.havenith@uliege.be (H.-B.H.)

4 Dipartimento di Scienze dell'Ambiente e della Terra, Università degli Studi di Milano-Bicocca, Piazza della Scienza 1/U4, 20126 Milano, Italy; gisela.domej@unimib.it

* Correspondence: farkhod.hakimov@doct.uliege.be

\section{check for}

updates

Citation: Hakimov, F.; Domej, G.; Ischuk, A.; Reicherter, K.; Cauchie, L.; Havenith, H.-B. Site Amplification Analysis of Dushanbe City Area,

Tajikistan to Support Seismic

Microzonation. Geosciences 2021, 11 154. https://doi.org/10.3390/ geosciences 11040154

\section{Academic Editors:}

Jesus Martinez-Frias and

Giovanni Barreca

Received: 15 February 2021

Accepted: 28 March 2021

Published: 31 March 2021

Publisher's Note: MDPI stays neutral with regard to jurisdictional claims in published maps and institutional affiliations.

Copyright: (c) 2021 by the authors. Licensee MDPI, Basel, Switzerland. This article is an open access article distributed under the terms and conditions of the Creative Commons Attribution (CC BY) license (https:/ / creativecommons.org/licenses/by/ $4.0 /)$.

\begin{abstract}
Being a country exposed to strong seismicity, the estimation of seismic hazard in Tajikistan is essential for urbanized areas, such as the rapidly growing capital city Dushanbe. To ensure people's safety and adequate construction work, a detailed seismic microzonation is the key to proper hazard planning. Existing estimations of seismic hazard date back to 1978; they are based on engineering geological investigations and observed macroseismic data. Thereupon relies the Tajik Building Code, which considers seismic intensities according to the Medvedev-Sponheuer-Karnik Scale, MSK-64. However, this code does not accurately account for soil types, which vary considerably in Dushanbe-not only by their nature, but also due to increasing anthropogenic influences. In this study, we performed a series of analyses based on microtremor array measurements, seismic refraction tomography, and instrumental data recording from permanent stations for standard spectral ration and from mobile seismic stations for the horizontal to vertical spectral ratio in order to provide a comprehensive full-cover microzonation of Dushanbe accounting for soil types. Our results identify several critical areas where major damage is likely to occur during strong earthquakes.
\end{abstract}

Keywords: ambient noise measurements; seismic refraction tomography; instrumental data recording; site effect; soil characteristics; borehole data; microzonation

\section{Introduction}

Similar to other big agglomerations in Central Asia (such as the Uzbekistan capital Tashkent or the Kyrgyzstan capital Bishkek), Dushanbe with its outskirts (Figure 1a,b) is at particular risk from earthquakes and the associated secondary hazards due to its close vicinity to two active fault systems. The Hissar-Kokshaal Fault passes some 10-15 km north of the city, and the Ilyak-Vaksh Fault crosses at about $20-25 \mathrm{~km}$ in the south. For both fault systems Babaev et al. [1] estimate maximum $\mathrm{M}_{\mathrm{W}}$ magnitudes of 7.5 and 6.5, respectively (see Figure 1).

First reliable earthquake records in Tajikistan date back to the 1895s. Since that time more than 20 earthquakes with magnitudes equal or greater than 7.0 have occurred [2]. Among the latter, the Karatag Earthquake in $1907\left(\mathrm{M}_{\mathrm{W}}=7.4\right)$, the Sarez Earthquake in $1911\left(\mathrm{M}_{\mathrm{W}}=7.4\right)$ and the Khait Earthquake in $1949\left(\mathrm{M}_{\mathrm{W}}=7.4\right)$ can be cited as examples for catastrophic events [3], although not for Dushanbe (Figure 1).

A more recent and also very damaging earthquake near Dushanbe was located in the Tajik Depression in South-Western Tajikistan (Figure 1) — the Hissar Earthquake on 22 January $1989\left(\mathrm{M}_{\mathrm{W}}=5.8\right)$. With a very shallow depth of about $5 \mathrm{~km}$, the intensity degree 
VII (i.e., "very strong") on the Medvedev-Sponheuer-Karnik Scale (MSK-64; [4]) was reached in the settlement of Hissar causing small direct damage on buildings, but triggered extensive liquefaction phenomena and related landslides in loess deposits. The villages of Sharora and Okuli-Poen were affected by mudflows destroying more than 100 houses, and 247 persons died. At a distance of $13 \mathrm{~km}$ from Dushanbe, the Hissar Earthquake was felt with an intensity of V units (i.e., "fairly strong") according to the MSK-64 scale [5].

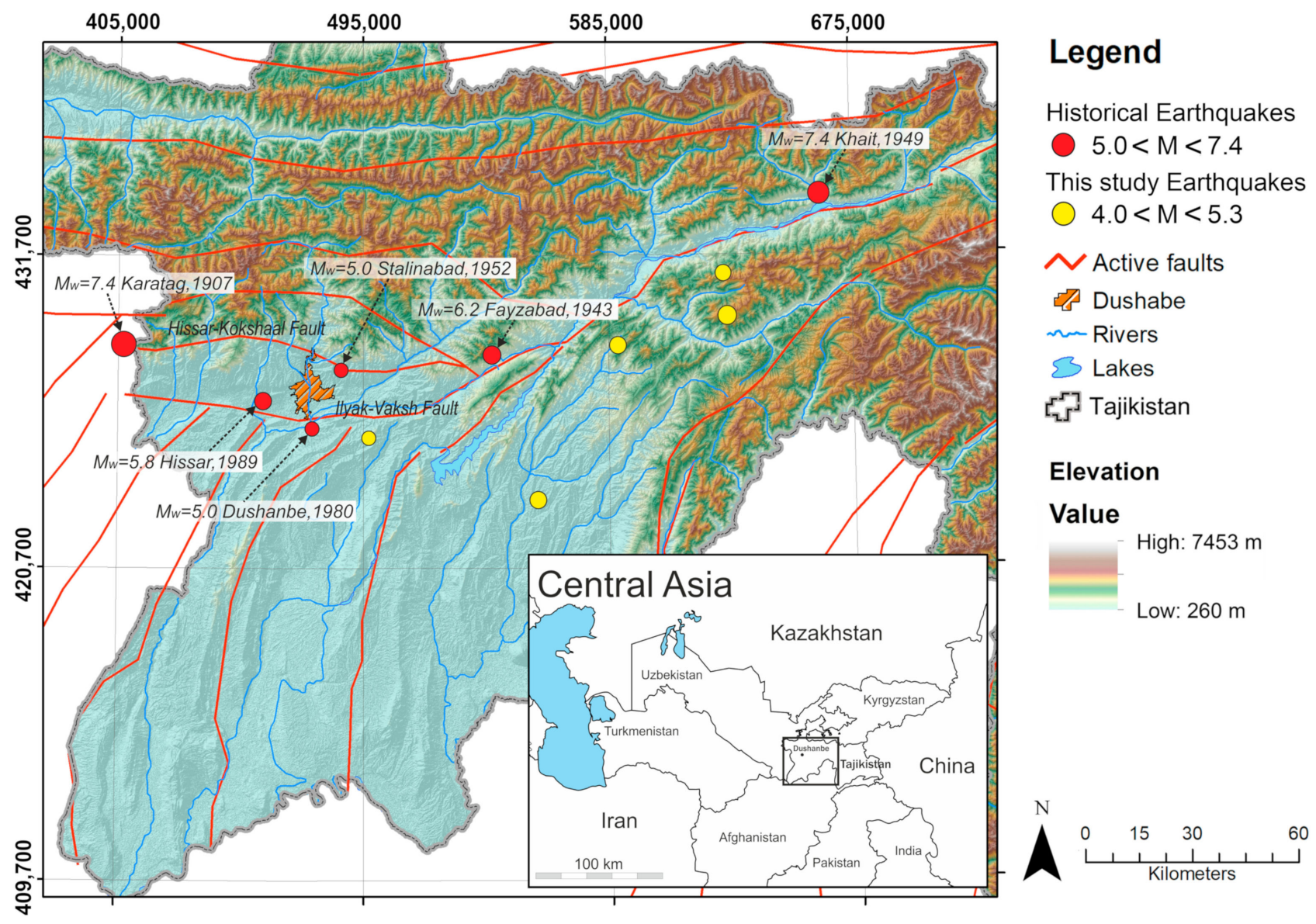

Figure 1. Study Area: Location of Tajikistan in Central Asia and the extent of the capital Dushanbe. The red circles show historical earthquakes, and the yellow circles show local earthquakes used in this study. The red lines show the most important seismogenic faults. Faults mentioned in the text are labeled.

For seismic hazard assessment, seismic sources located at different distances from Dushanbe are of particular interest. The highest hazard arises from earthquakes within a radius of 30-50 km and at depths of 5-30 km [6]. As proposed by Babaev et al. [1], there is indeed a strong probability of occurrence of such events within the mentioned radius for example along the closely located Hissar-Kokshaal Fault. An intensity of IX units (i.e., "destructive") on the MSK-64 scale resulting from such close and shallow earthquakes could be reached at different places throughout Dushanbe [7]. The fact that the ground beneath the city consists mainly of different types of sediments and sedimentary rocks plays here an important role, as the material tends to amplify and prolong the seismic shaking, and, thus, enhances the hazard potential. This latter phenomenon is known as "site effects".

Remote earthquakes beyond the mentioned radiuses, for instance from the PamirHindukush Subduction Zone, may become dangerous if they develop great magnitudes, and if the duration may be about one or even several minutes. The results might be vibratory motions with specifically unfavorable spectral compositions, which can spread 
over vast areas and become a danger for high buildings. Intensities could reach up to VI units (i.e., "strong") on the MSK-64 scale [8].

Even though the need of detailed seismic hazard assessment in Tajikistan is apparent, studies on the area are sparse. Only recently, intensity assessments for Central Asia were proposed by Bindi et al. [9], and Pilz et al. [10] evaluated the seismic risk for Dushanbe. Additionally, some neighboring regions were studied [11]. On a global scale, a seismic hazard map was made available by the Global Seismic Hazard Assessment Program (GSHAP; [12,13]) on which peak ground accelerations (PGAs) of $0.40-0.48 \mathrm{~g}\left(=3.92-4.71 \mathrm{~m} / \mathrm{s}^{2}\right)$ are assigned to Western Tajikistan; PGA values of $0.38-0.40 \mathrm{~g}$ $\left(=3.73-3.92 \mathrm{~m} / \mathrm{s}^{2}\right)$ were estimated by Ischuk et al. [14] for Dushanbe. However, so far there was no comprehensive full-cover microzonation available for Dushanbe in particular-a fact that our site characterization study should remedy.

Considering the fast expansion of Dushanbe entailing new high rise constructions, seismic hazard maps should incorporate two main aspects. On one hand, maps must reflect the seismic activity potential and ground motions in terms of one or more parameters-in terms of intensities according to the MSK-64 scale, and in the terms of accelerations (PGApeak ground acceleration). On the other hand, the local soil response to seismic impacts must be considered in order to provide accurate maps, which could subsequently be used for hazard mapping and during the development of a more accurate seismic building code.

Typical for most urbanized areas is a dense agglomeration inducing a wide range of conditions and disturbing factors, which limit the application of many geophysical methods that allow for complex seismic microzonation. In many cases, invasive methods (e.g., drilling and borehole measurements) are impossible to implement [15]. For this reason, only non-invasive methods were used for data acquisition (Table 1): microtremor array measurements (MAMs), seismic refraction tomography (SRT), and instrumental data recording from temporary and permanent and from mobile seismic stations for long- and short-term acquisition, respectively. The use of these methods individually or in combination has proven to be successful for detailed seismic characterization and microzonation in the past (e.g., [10,16-26]). The newly assessed data was combined with local geological and geotechnical data in the form of lithological maps and cross sections as well as borehole logs provided by the Head Institute of Engineering and Technical Surveys of the State Construction Committee of Tajikistan (HIETSCCT; [27]).

Table 1. Non-invasive methods used for the collection of new data. Compiled data $\left.{ }^{*}\right)$ from the Head Institute of Engineering and Technical Surveys of the State Construction Committee of Tajikistan (HIETSCCT; 2019) were evaluated and adapted to meet the requirements of our study.

\begin{tabular}{|c|c|c|c|}
\hline Method & Assessed Data & Processing & Results \\
\hline $\begin{array}{c}\text { 175-Horizontal to Vertical } \\
\text { Spectral Ratio (HVSR) } \\
\text { measurements }\end{array}$ & $\begin{array}{l}\text { passive vibration } \\
\text { (ambient noise at } \\
\text { 30-min intervals) }\end{array}$ & $\begin{array}{l}\text { Horizontal to Vertical Spectral } \\
\text { Ratio (HVSR) }\end{array}$ & $\begin{array}{l}\text { Fundamental Resonance } \\
\text { Frequency Map }\end{array}$ \\
\hline $\begin{array}{l}\text { 9-Seismic Refraction } \\
\text { Tomography (SRT) profiles }\end{array}$ & $\begin{array}{l}\text { active vibration } \\
\text { (P-wave) }\end{array}$ & P-wave inversion & $\begin{array}{c}\text { P-wave velocity }\left(\mathrm{V}_{\mathrm{p}}\right) \text { patterns, } \\
\text { subsurface structures }\end{array}$ \\
\hline $\begin{array}{l}\text { 5-Microtremor Array } \\
\text { Measurements (MAM) }\end{array}$ & $\begin{array}{l}\text { passive vibration (ambient } \\
\text { noise at two-hour intervals) }\end{array}$ & $\begin{array}{l}\text { Spatial Autocorrelation } \\
\text { (SPAC), Rayleigh Wave }\end{array}$ & $\begin{array}{c}\text { Dispersion curves, } \\
\text { S-wave velocity }\left(\mathrm{V}_{\mathrm{S}}\right) \text { patterns }\end{array}$ \\
\hline $\begin{array}{l}\text { 5- temporary seismic stations } \\
\text { recordings \& } 1 \text { permanent } \\
\text { reference station }\end{array}$ & $\begin{array}{l}\text { passive vibration } \\
\text { (instrumental data) }\end{array}$ & $\begin{array}{l}\text { Standard Spectral Ratio (SSR) } \\
\text { from earthquake }\end{array}$ & Amplification factors \\
\hline data compilation $\left(^{*}\right)$ & $\begin{array}{c}\text { lithological maps and cross } \\
\text { sections } \\
\text { data of } 60 \text { boreholes }\end{array}$ & $\begin{array}{l}\text { (data evaluation and } \\
\text { adaption) }\end{array}$ & $\begin{array}{c}\text { Surface lithology, subsurface } \\
\text { structures }\end{array}$ \\
\hline
\end{tabular}




\section{Local Geology and Previous Microzonations}

Dushanbe is located at the foot of the Hissar Range in an east-west trending valley with the same name and about $70 \mathrm{~km}$ long and $20 \mathrm{~km}$ width. The main river in the Hissar Valley is the Kafirnigan River flowing westwards; first and second order tributaries are the Varzob River and the Luchob River and the Hissar Canal (Figure 2a). The planes to both sides of the Kafirnigan and the Varzob Rivers are covered with extensive layers of alluvial and proluvial deposits; thus, Dushanbe is built on those quaternary sedimentary sequences consisting of gravel and sand alternating with layers of loam soils and loess (Figure 2a).
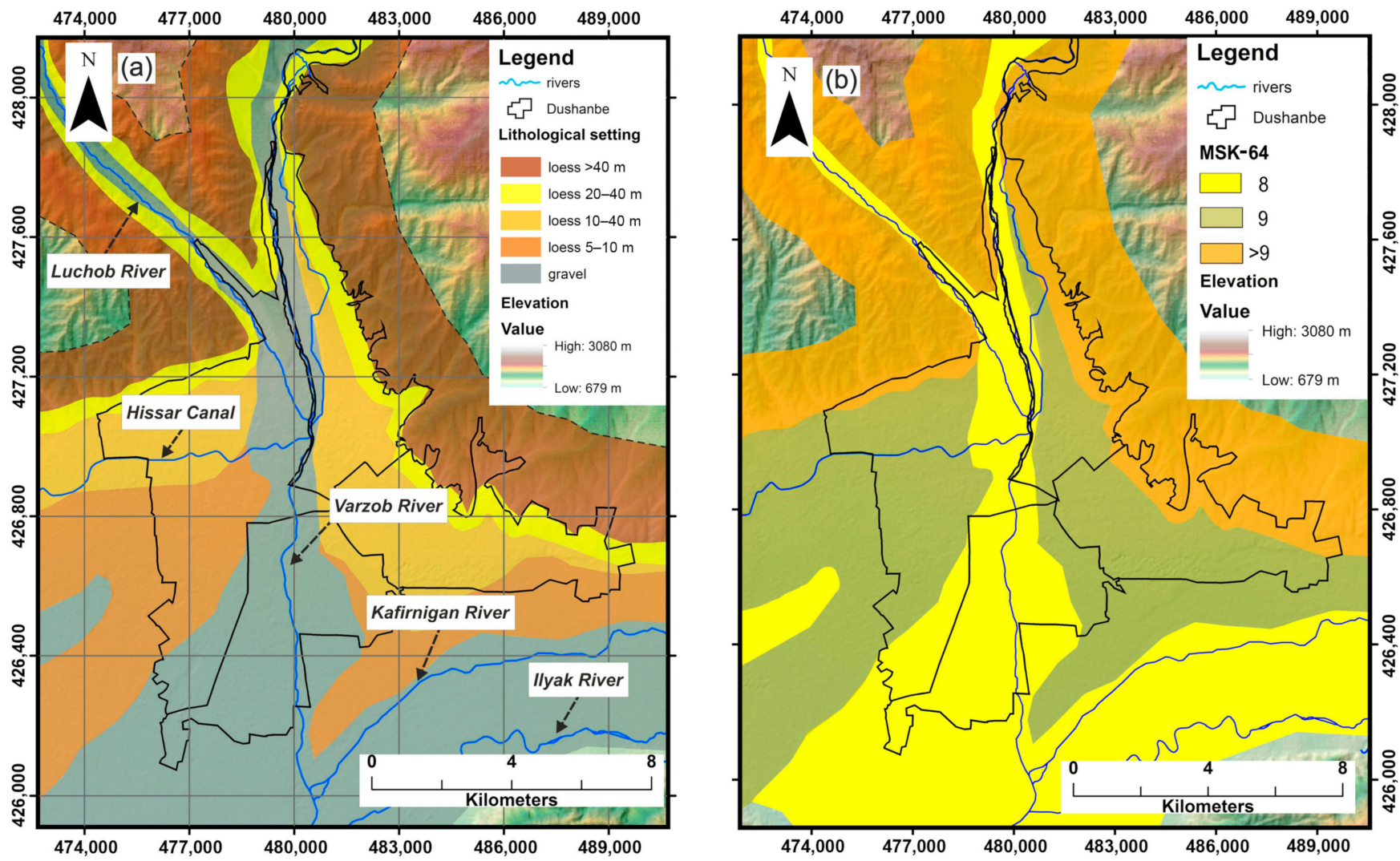

Figure 2. (a) River system and lithology in the area of Dushanbe (after [28]) and (b) seismic microzonation of Dushanbe by [29] based on the acoustic stiffness of the soils in terms of the MSK-64 scale.

Quaternary sediments and sedimentary rock reach depths of up to $300 \mathrm{~m}$. The chronologically older Paleogene sedimentary rocks beneath have thicknesses of $600 \mathrm{~m}$ to $1400 \mathrm{~m}$; and Upper and Lower Cretaceous sedimentary rocks are believed to be between 600 and $900 \mathrm{~m}$ thick. In total, thus, Meso- and Cenozoic deposits extend to about $3 \mathrm{~km}$ in depth [30-33]. Mesozoic and tertiary rocks consist mainly of sandstone, but also to large parts of conglomerates, clays, limestone, and gypsum. Sandstone is present beneath almost all parts of Dushanbe under the uppermost gravel and loess covers (see above in Figure 2a); the only sandstone outcrops are found in the north across flanks bordering the Varzob and Luchob Valleys.

The major part of the city is located on three terraces and partly on the adjoining foothills (regionally termed in Central Asia, "adyrs"-are hill sloping foothills and individual hills and ridges on the valleys' slopes) and on diluvial terrain at altitudes of 800-900 m above sea level. The Varzob River floodplain starts with a narrow valley in the north, gradually expands southwards following the Varzob River, and consists mainly of gravel with embedded sand layers and greater boulders. This sequence of deposits is found likewise beneath the second and the third terraces in Dushanbe area. Thicknesses generally decrease from about $300 \mathrm{~m}$ in the center of Dushanbe and the right bank of the Varzob River 
towards the north, west, and east thinning out to thicknesses of only 20-40 m. The second terrace, called Hissar Terrace, rises with a 1-3 m high cliff above the Varzob flood-plain. It consists on average of 5-10 m thick loess covers. Additionally, the third terrace comprises mainly loess layers with an average thickness of 10-30 m and a cliff of 12-18 $\mathrm{m}$ towards the second terrace. With a gradient of $3 \%$ it is slightly inclined towards the southwest (see the cross section in Figure 3c). The outskirts of Dushanbe show complex geological structures, which are still poorly explored-even to a depth of several tens of meters.

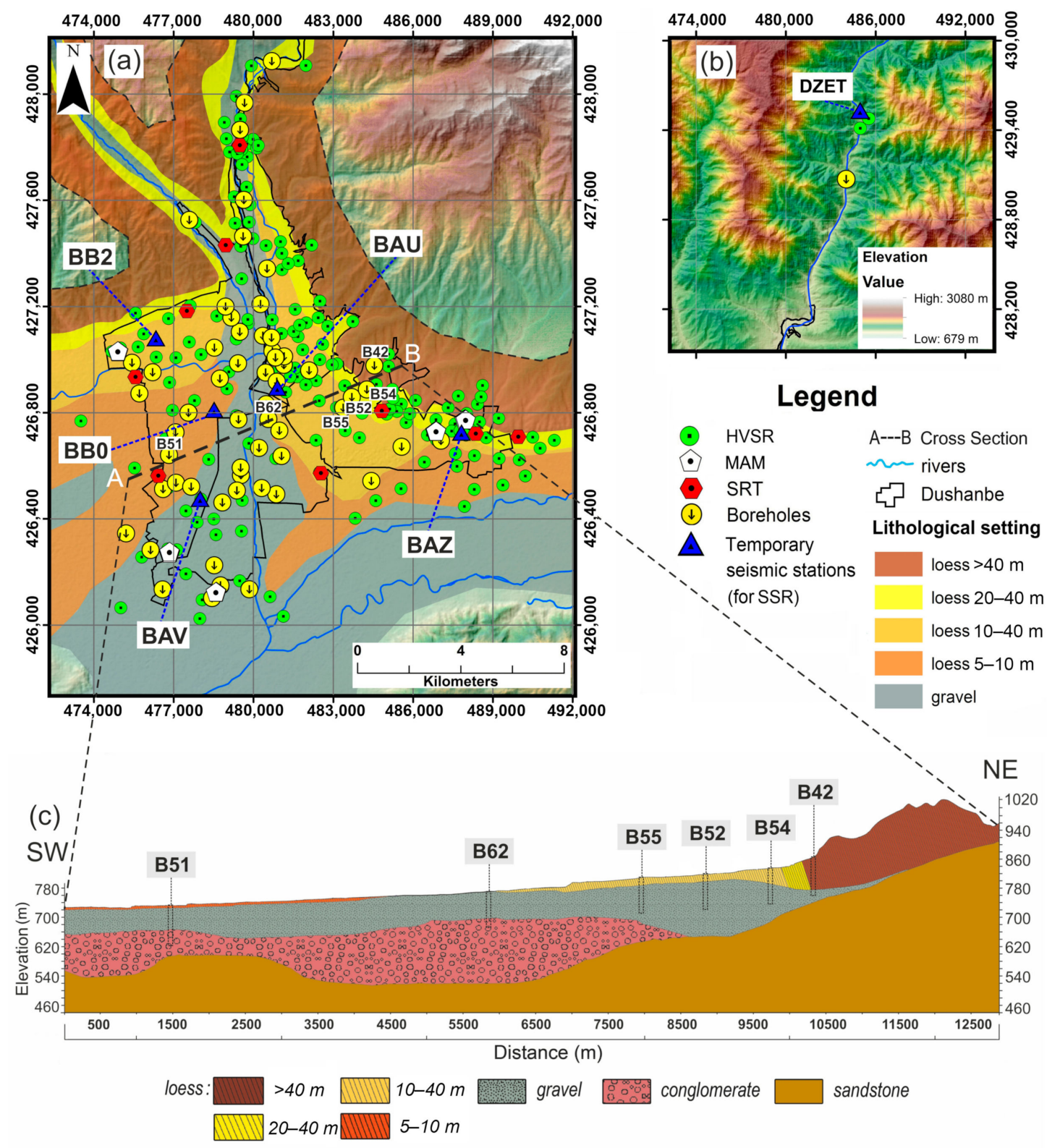

Figure 3. Locations of 60 boreholes, 5 microtremor array measurements (MAM), 9 seismic refraction tomography (SRT) profiles, 5 temporary seismic stations for standard spectral ratio (SSR) measurements, and 175 mobile seismic stations for horizontal to vertical spectral ratio (HVSR) measurements (a). The permanent seismic station Djerino (DZET, located in (b) serves as reference and is installed on a granite bedrock outcrop some $14 \mathrm{~km}$ north of Dushanbe (maps with hill shade and colored shuttle radar topography mission digital elevation model, SRTM DEM, of $30 \mathrm{~m}$ resolution as the background). Lithological cross section cutting through Dushanbe from southwest to northeast along profiles sketched from available boreholes (c); after the Head Institute of Engineering and Technical Surveys of the State Construction Committee of Tajikistan [27,29]. The numbers in the cross section (c) indicate examples of borehole logs (Section 4.1). 
Water supply to the city and its population resulted in a large number of boreholes drilled in Dushanbe. Data from boreholes is a valuable resource that helps with the interpretation of the passive seismic surveys and allows one to obtain various preliminary cross section of the sedimentary cover from southwest to northeast (Figure 3c). Borehole data and lithological cross section were collected from the Head Institute of Engineering and Technical Surveys of the State Construction Committee of Tajikistan (HIETSCCT; [27]) and a previous study of [29] to support the mapping of the lithological units across Dushanbe, the delineation of underground layer sequences and subsurface structures within the sedimentary soils and, finally, the interpretation of the results of the applied geophysical methods. In total, 60 boreholes were drilled to depths of 30-200 m across the city (Figure 3).

In terms of tectonics, Dushanbe is located in an area affected by strong seismicity regularly experiencing shallow (focal depths $\leq 45 \mathrm{~km}$ ) and deep (focal depths $\geq 70 \mathrm{~km}$ ) earthquakes. The frequency of medium to strong events is shown in Figure 4, in which epicenters of earthquakes from the Central Asia Seismic Risk Initiative, Earthquake Modeling for Central Asia Catalogue (CASRI-EMCA; [34,35]) over the period from 850 to 2015, and updated from USGS catalogue (U.S. Geological Survey) over the period from 2015 to 2020. Strong earthquakes in Western Tajikistan with magnitude $4.5 \leq \mathrm{M} \leq 8.2$ are shown in Figure 4.
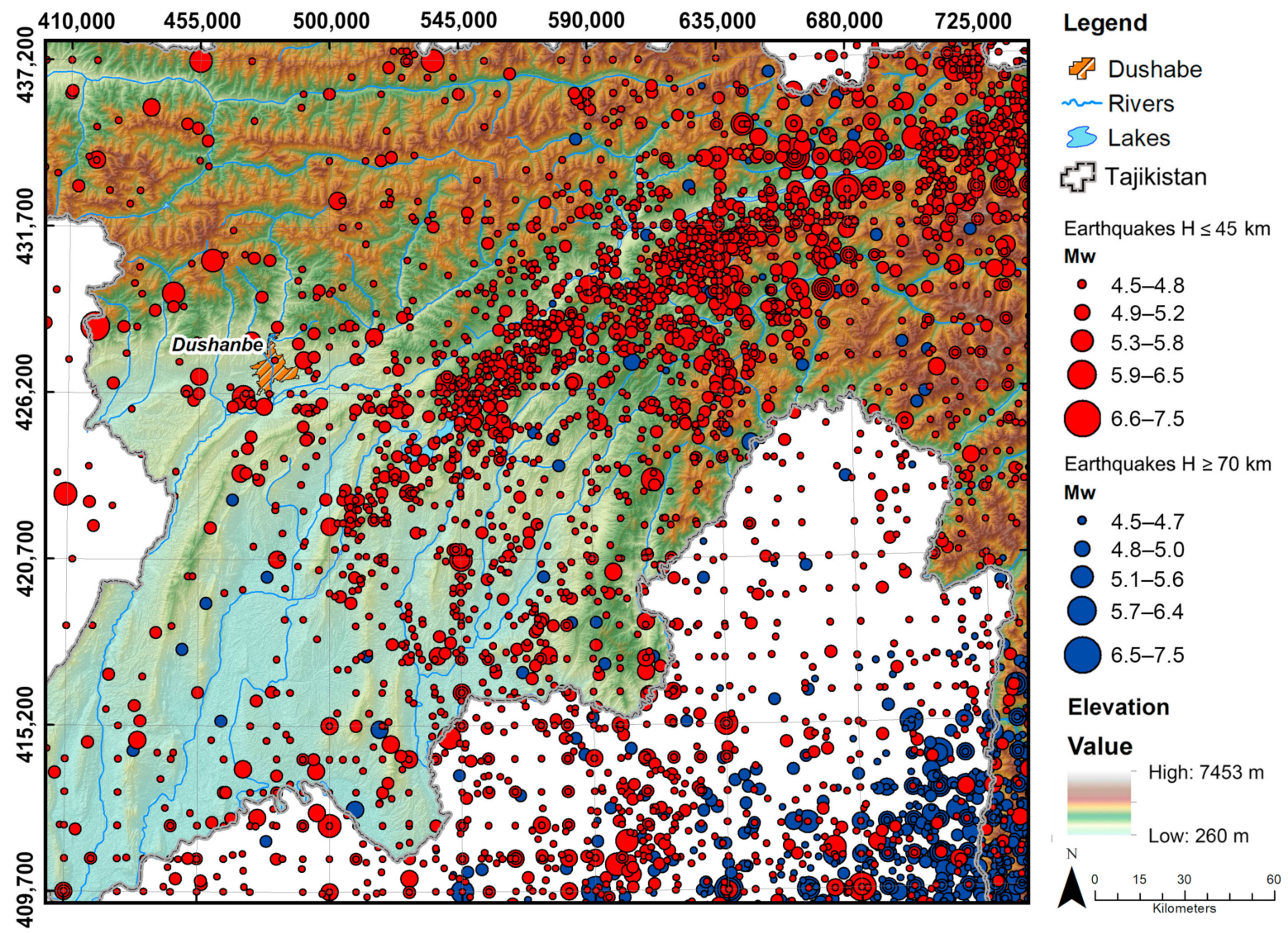

Figure 4. Epicenters of shallow (focal depths $\leq 45 \mathrm{~km}$; marked in red) and deep (focal depths $\geq 70 \mathrm{~km}$; marked in blue) earthquakes from the Central Asia Seismic Risk Initiative, Earthquake Modeling for Central Asia Catalogue (CASRIEMCA; [34,35]) over the period from 850 until 2015, and updated from USGS catalogue (U.S. Geological Survey) over the period from 2015 until 2020.

Western Tajikistan is crossed by several major faults and subfaults. Two of the major faults are located in close vicinity to Dushanbe: the Hissar-Kokshaal Fault in the north and the Ilyak-Vaksh Fault in the south with our estimation of possible maximum magnitudes $\left(\mathrm{M}_{\mathrm{w}}\right)$ of 7.6 and 7.5 , respectively (see Figure 1). In an earlier study with the aim of a general 
seismic zonation of Dushanbe, Babaev et al. [8] hypothesized that the city could experience intensities with up to IX units (i.e., "destructive") on the MSK-64 scale. The zonation is still in use as a reference for the seismic building code in Tajikistan. The earliest seismic zonations date back to the 1930s, and were based on soil types [36]. A combined work of Nazarov and Nechaev [37], Kogan et al. [38], and Oripov [39] consist of two separate zonations with intensity from VIII units (i.e., "damaging") to >IX units (i.e., "destructive) on the MSK-64 scale for buildings with less and more than five floors, respectively. Both seismic zonations are the basis for the Tajik Seismic Building Code currently in use. The latest seismic zonation was established by [29] based on the two separate zonings and use the same partition of intensity units (Figure $2 b$ ).

The first step towards an area-wide site characterization based on soil response was carried out by Pilz et al. [10] within the framework of the regional program "Earthquake Modeling for Central Asia" (EMCA) by the Global Earthquake Model Foundation (GEM Foundation), which emphasizes the refinement of existing seismic hazard maps for cities in Central Asia. Considering the complex sequence of lithology and the thereby entailed significant lateral and vertical variations of soil properties, the authors underlined the need for a new assessment of seismic risk based on site effects and the vulnerability of the buildings. A dense seismic network allowed for the assessment of amplification patterns and shear wave velocity $\left(\mathrm{V}_{\mathrm{S}}\right)$ gradients, whereas single-station noise measurements shed light on ground motion variability. Remote-sensing data delivered additional information on the vulnerability of the building stock.

However, with the steadily growing number of (also large) buildings constructed on a layered sequence of sedimentary deposits favoring the amplification and the prolongation of vibratory motion, a detailed seismic zonation of Dushanbe is essential. This study provides new inputs for a future microzonation based on a multimethodological approach.

\section{Applied Geophysical Methods}

In order to better understand the local seismic response of the different soil types and subsurface structures, the following non-invasive seismic methods were conducted: five microtremor array measurements (MAM), nine seismic refraction tomography (SRT) profiles, five temporary seismic stations for standard spectral ratio (SSR) measurements with one permanent station serving as reference, and 175 horizontal to vertical spectral ratio (HVSR) measurements (Table 1). The results of recent measurements were combined with lithological maps, cross sections and data from 60 borehole logs [27]. Figure 3 presents an overview of the locations of new investigations and the boreholes. All methods were completed between 2018 and 2020, and borehole log from 1965 to 2019.

\subsection{Horizontal to Vertical Spectral Ratio (HVSR) Measurements from Mobile Seismic Stations}

Originally, the method of measuring the horizontal to vertical spectral ratio (HVSR) from ambient noise or passive vibration input was popularized by [40] and largely used for two decades. Nakamura [40] described that the HVSR between horizontal and vertical ambient noise records is related to the fundamental resonant frequency (natural frequency) of the soil $\left(\mathrm{f}_{0}\right)$ when a sedimentary deposits lies over bedrock. This method involves evaluating the ratio of the amplitude spectra obtained from the horizontal and vertical components of the seismometer [41]; results characterize the frequency spectra in terms of resonance and predominant frequencies [42]. The method is widely used in site effect assessments and in geotechnical studies [43-45]. The most common field of application is seismic microzonation of urban areas (e.g., [17,19-21,24,46]).

A total of 175 ambient noise recordings were carried out throughout Dushanbe (located in the map in Figure 3) using a mobile Mark L-4C-3D seismometer with a resonance frequency of $1 \mathrm{~Hz}$ connected to an EarthData PR6-24 recorder with GPS timing. At each site, ambient noise was recorded during $30 \mathrm{~min}$ at a rate of 100 samples per second $(100 \mathrm{~Hz})$ for statistical signal stabilization. In addition, the azimuth of each peak was estimated to calculate the HVSR in all orientations of the horizontal plane. 
Almost all measurements were placed directly on soils or gravel; only a few measurements were made on tarmac. To ensure sufficient accuracy, the measurements have never been carried out in critical weather conditions (i.e., with rain and/or strong wind) as recommended by the 'Site Effects Assessment using Ambient Excitations' (SESAME) project [47]. Most of the ambient noise recordings were made in the central, northern, and eastern parts of the city with an interval of at least $500 \mathrm{~m}$ between each other, while some specific recording sites were selected to cover typical topographic areas, such as, for example, mountain slopes, river junction, or free fields (Figure 3a).

\subsection{Seismic Refraction Tomography (SRT)}

The seismic refraction tomography (SRT) is a common method to assess the P- and Swave velocities of soils, and is widely used in the field of geotechnical engineering [48-51]. The frequent usage of SRT is owed to its simplicity, flexibility, and rapidity; the limitation of investigations to depths of several tens of meters could, however, be regarded as drawback. By applying inversion methods (i.e., either P- and/or S-wave inversions) on SRT profiles, $\mathrm{P}$ - and/or S-wave velocity patterns within the underground are obtained, which shed light on subsurface structures.

In order to assess the seismic soil properties, we performed nine SRT in zones of different building densities throughout Dushanbe, each of which had a length of $115 \mathrm{~m}$ (DSP1-DSP9 in Figure 3; Table 2). Active vibratory input was recorded in the form of P-waves using 24 geophones sensitive to $4.5 \mathrm{~Hz}$ and spaced at intervals of $5 \mathrm{~m}$, all of which were connected to a 16-bit Geometrics ES-3000 Seismograph. Seismic impacts were generated on the ground surface by club hammer strokes on a metal plate at five different positions relative to the aimed seismic profile: one at each profile end, one in between, and two with an offset of $25 \mathrm{~m}$ in straight prolongation to the profile. All profiles were orientated roughly in the north-south direction. Table 2 provides information on the location, position relative to the three terraces and prevalent soil types visible from the surface. Recorded data was processed with the software SARDINE [52] in 2D after picking P-wave arrival times manually. In order to ensure correct wave propagation within a half-space, the minimum and maximum expected P-wave velocities $\left(\mathrm{V}_{\mathrm{p}}\right)$ were limited to $300 \mathrm{~m} / \mathrm{s}$ (for air) and $4000 \mathrm{~m} / \mathrm{s}$ (for hard sandstone), respectively. P-wave inversion was carried out using the simultaneous iterative reconstruction technique (SIRT; [53]) implemented in SARDINE.

Table 2. Seismic refraction tomography (SRT) profiles with details on location, position relative to the three terraces and prevalent soil types visible from the surface.

\begin{tabular}{cccc}
\hline Profile & Position & Terrace & Uppermost Soil Types \\
\hline DSP1 & $100 \mathrm{~m} \mathrm{E}$ of the Varzob River (left bank) & $1 \mathrm{st}$ & gravel, with loess on top \\
DSP2 & $500 \mathrm{~m} \mathrm{~N}$ of the Luchob River (left bank) & 1st & loess, loam, some gravel/sand \\
DSP3 & $2 \mathrm{~km} \mathrm{~N}$ of the Hissar Canal (left bank) & loess (up to $40 \mathrm{~m}$ ) \\
DSP4 & $300 \mathrm{~m} \mathrm{~S}$ of the Hissar Canal (right bank) & 3rd & loess (up to $40 \mathrm{~m}$ ) \\
DSP5 & $3 \mathrm{~km} \mathrm{~W}$ of the Varzob River (right bank) & 2nd & gravel, with loess on top \\
DSP6 & $2.5 \mathrm{~km}$ E of the Varzob River (left bank) & 3rd & gravel, with loess on top \\
DSP7 & $4.5 \mathrm{~km} \mathrm{~N}$ of the Kafirnigan River (right bank) & 3rd & loess (>40 m) \\
DSP8 & $3 \mathrm{~km} \mathrm{~N}$ of the Kafirnigan River (right bank) & 3rd & loess (>40 m) \\
DSP9 & $3 \mathrm{~km} \mathrm{~N}$ of the Kafirnigan River (right bank) & 3rd & loess ( $>40 \mathrm{~m})$ \\
\hline
\end{tabular}

\subsection{Microtremor Array Measurements (MAMs)}

Ambient noise measurements have proven useful for 2D and 3D seismic subsurface characterizations to derive shear wave velocity $\left(V_{S}\right)$ patterns within the underground [54-58]. Being a passive method, it is particularly suitable for the evaluation of site effects and subsequently of the seismic hazard [16,43]. Usually, frequencies ranging from 1 to $25 \mathrm{~Hz}$ are recorded capturing mainly ambient noise induced by human activity (e.g., traffic or heavy machinery) and natural phenomena (e.g., wind or water courses); this noise is referred to as microtremor [59]. 
Microtremor array measurements (MAMs) allow us to identify of the phase velocities of surface waves (vertical components of the Rayleigh Waves were mainly analyzed). Via the method of spatial autocorrelation (SPAC; [60-63]), dispersion curves of Rayleigh Wave phase velocities are obtained and then processed through surface wave inversion to compute the $1 \mathrm{D}$ (vertical) shear wave velocity $\left(\mathrm{V}_{\mathrm{S}}\right)$ distribution of the underground. Dispersion curves are commonly shown in graphs plotting shear wave velocities $\left(\mathrm{V}_{\mathrm{S}}\right)$ as a function of wavelengths (or frequencies). MAM with resulting vertical shear wave velocity $\left(V_{S}\right)$ variations are representative for a single location bounded by the array polygon.

In this study, we established five MAM in the eastern (DA1 and DA2), the southern (DA3 and DA4) and the western (DA5) parts of the city (DA1-DA5 in Figure 3; Table 3). For this purpose, we used five three-component Trillium Compact 20s Seismometers connected to a 24-bit DATA-CUBE3 Recorder in a pentagonal geometry configuration without an additional central sensor. The radius of the MAM usually varied between 45 and $50 \mathrm{~m}$ depending on the location. Record durations lasted for two hours for each MAM with a sampling rate of $100 \mathrm{~Hz}$. For all MAM, only vertical components were used for processing Rayleigh Waves from ambient noise.

Table 3. Microtremor array measurements (MAM) with details on location, position relative to the three terraces, and prevalent soil types visible from the surface.

\begin{tabular}{cccc}
\hline Array & Position & Terrace & Uppermost Soil Types \\
\hline DA1 & $3.5 \mathrm{~km} \mathrm{~N}$ of the Kafirnigan River (right bank) & 3rd & loess $(>40 \mathrm{~m})$ \\
DA2 & $3.3 \mathrm{~km} \mathrm{~N}$ of the Kafirnigan River (right bank) & 3rd & loess (<40 m) \\
DA3 & $1.5 \mathrm{~km} \mathrm{~W}$ of the Varzob River (right bank) & 2nd & gravel \\
DA4 & $3.2 \mathrm{~km} \mathrm{~W}$ of the Varzob River (right bank) & 3nd & gravel \\
DA5 & $700 \mathrm{~m} \mathrm{~N}$ of the Hissar Canal (left bank) & 3rd & loess $(<40 \mathrm{~m})$ \\
\hline
\end{tabular}

\subsection{Standard Spectral Ratio (SSR) Measurements from Temporary Seismic Stations}

Earthquake shaking has been recorded over a period of five months at five temporary seismic stations in the city and at one permanent seismic station located on a granite outcrop some $14 \mathrm{~km}$ north of Dushanbe serving as reference (located at "SSR" points in the map in Figure 3). For the five locations within the city, Trillium Compact 20s Seismometers were used connected to a 24-bit DATA-CUBE3 Recorder. The reference station in Djerino (DZET; Figure $3 b$ ) is equipped with a CMG-3ESPC Seismometer connected to a Güralp CMG-DM24-6 Channel Recorder. Table 4 provides information on the location, position relative to the three terraces and prevalent soil types visible from the surface.

Table 4. The temporary seismic stations for standard spectral ratio (SSR) with details on location, position relative to the three terraces and prevalent soil types visible from the surface.

\begin{tabular}{cccc}
\hline Station & Position & Terrace & Uppermost Soil Types \\
\hline DZET & $14 \mathrm{~km} \mathrm{~N}$ of Dushanbe of the Varzob River (left bank) & 3rd & granite bedrock \\
BB2 & $1 \mathrm{~km} \mathrm{~N}$ of the Hissar Canal (left bank) & loess $(<40 \mathrm{rd})$ \\
BB0 & $1 \mathrm{~km} \mathrm{~W}$ of the Varzob River (right bank) & loess $(<10 \mathrm{~m})$ \\
BAU & $800 \mathrm{~m}$ E of the Varzob River (left bank) & $1 \mathrm{st}$ & loess $(<40 \mathrm{~m})$ \\
BAV & $2 \mathrm{~km} \mathrm{~W}$ of the Varzob River (right bank) & 3rd & gravel \\
BAZ & $3 \mathrm{~km} \mathrm{~N}$ of the Kafirnigan River (right bank) & 3rd & loess $(>40 \mathrm{~m})$ \\
\hline
\end{tabular}

The spectral amplitudes were calculated by the reference site method, more precisely by the standard spectral ratio method (SSR; [64]), by comparing the record of earthquakes in the study area with the records of the nearby reference station. Records from the reference site (station placed on the rock) are assumed to contain the same sources and effects on propagation as records from other sites $[10,24,65]$. This ratio can be calculated for all three components separately, i.e., vertical $(\mathrm{Z})$, north-south $(\mathrm{N})$, and east-west $(\mathrm{E})$, but it 
mostly applies to the average horizontal spectra (e.g., $[23,45,66,67])$. The spectral ratio can therefore directly deliver the site response $[22,45,65,66]$.

\section{Data Processing and Results}

\subsection{Comparison of the Borehole Data}

The seismic properties of soils are assessed in terms of seismic velocities $\left(V_{p}\right.$ and $\left.V_{S}\right)$ and other physical characteristics and their geological and geomorphological position. The properties of gravels are slightly variable. As for loess soils, their features depend on their geological and geomorphological position and are highly susceptible to changes due to anthropogenic factors.

The velocity of S-waves for loess in Dushanbe varies considerably, although the average characteristics are often close to $V_{S}=235 \mathrm{~m} / \mathrm{s}$ [29]. Higher values of the parameter are typical of loess soils developed on terraced surfaces and lower values are typical of the adyrs.

We compare the estimated lithological cross-section from southwest to northeast with existing borehole data (see Figure 3c). In the geotechnical map in Dushanbe [28], lithological profiles' cross-sections were included (see Figure 3a). Based on the map, the cross-section A-B (Figure 3c) is compared with the use example at six sites information of the borehole data. Figure 5 compares the borehole data with inverted Vs profiles from downhole data of the previous studies by [29]. The depths of the borehole data and Vs profile are up to $100 \mathrm{~m}$. Based on the borehole data, the soil in the south-west of the city is composed of thin layers of loess, gravel deposits, and conglomerate in the lower layers. In the center of the profile, according to the borehole data, the soil consists of gravel deposits, and conglomerates made of lime cement and rocks in the lower layers. In the north-eastern part, the total thickness of loess deposits within the study area varies, according to drilling and geophysical data, from 40 to $120 \mathrm{~m}$ at the junction of the foothill plain with a high terrace and to $160-200 \mathrm{~m}$ at the adyrs. Vs profiles, which correspond to gravel deposits, ranges from 380 to $550 \mathrm{~m} / \mathrm{s}$ and for conglomerate from 600 to $750 \mathrm{~m} / \mathrm{s}$ [29].
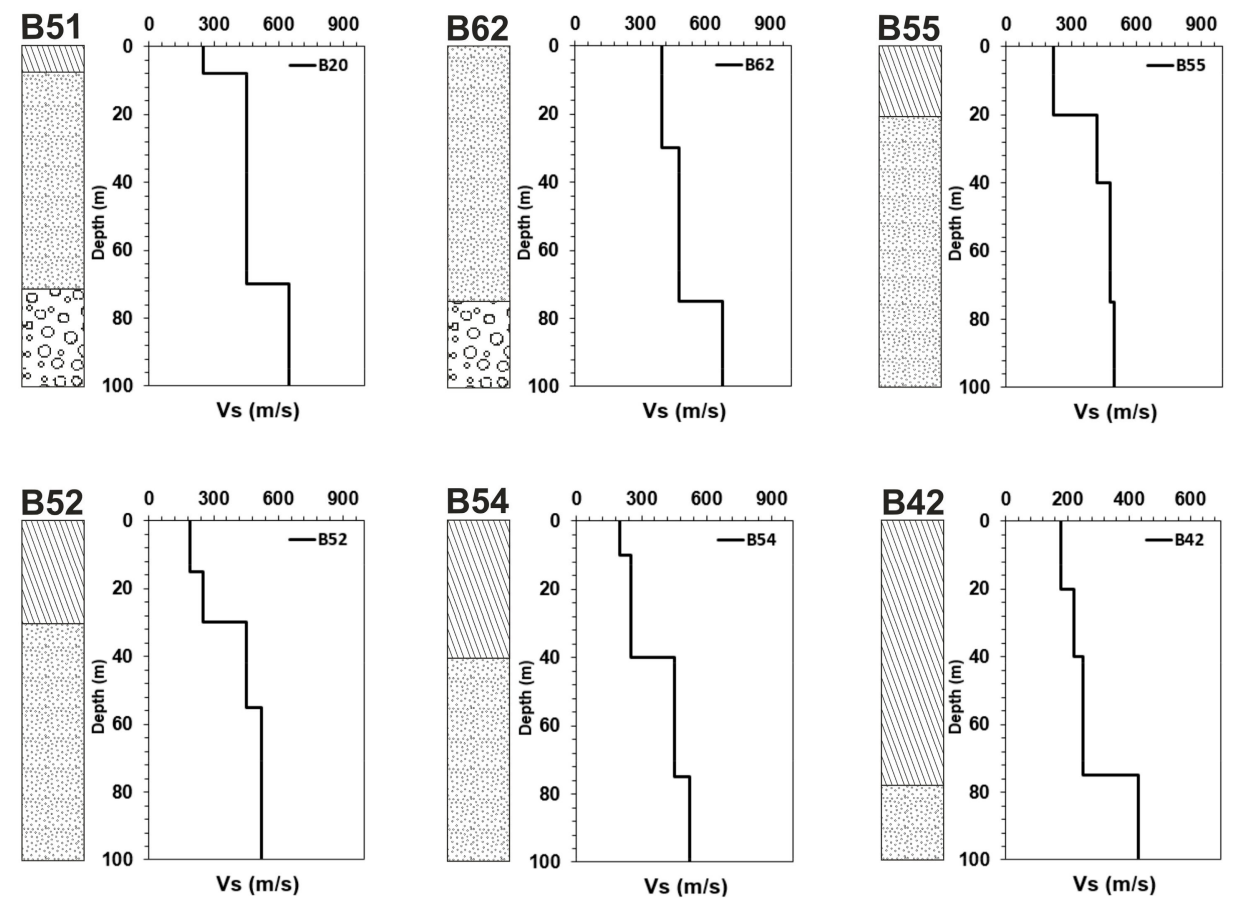

$M$ loess $\quad$ gravel 500 conglomerate

Figure 5. The borehole and downhole logs of the invasive technique based on the study of [29] allowed the determination of the shear-wave velocity profile with depth $\mathrm{V}_{\mathrm{S}}$ of the cross-section cutting through Dushanbe from west to east (Figure 3c). 


\subsection{Results of the Seismic Refraction Tomography (SRT) Profiles}

According to the estimated SRT profiles from nine locations (DSP1-DSP9 in Figure 6), the subsurface structures can be grouped into four classes of different P-wave velocities $<750 \mathrm{~m} / \mathrm{s}, 750-1250 \mathrm{~m} / \mathrm{s}, 1250-2500 \mathrm{~m} / \mathrm{s}$, and $2500-4000 \mathrm{~m} / \mathrm{s}$. Each of them is representative for different lithological layers: (i) loess layers with different thicknesses and degrees of compactness, (ii) gravel with embedded boulders and sand fillings, (iii) conglomerates (possibly intact rock), and (iv) sandstone bedrock. This link to lithological layers is supported by comparison with borehole data (Figure 3).

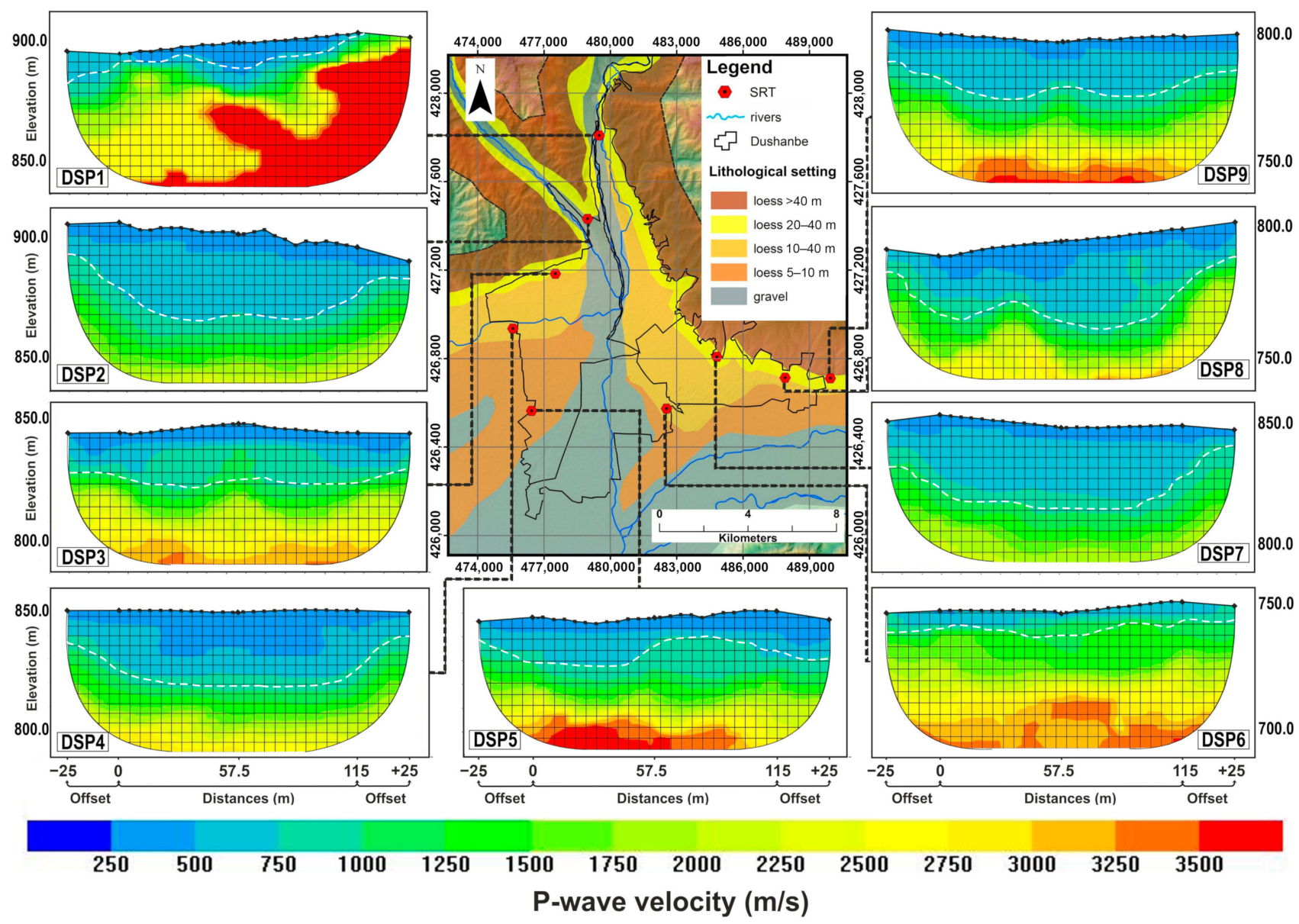

Figure 6. Results of the nine seismic refraction tomography (SRT) profiles, dash white line showed basis of loess layer.

The uppermost layer with P-wave velocities $<750-1250 \mathrm{~m} / \mathrm{s}$ corresponds to the second and third terraces' uppermost loess layers (Figure 6). SRT profiles DSP2, DSP3, and DSP4 in the northwestern part of the city show loess layers with a thickness of 30-35 m, whereas in the northeastern part close to the foothills, SRT profiles DSP7, DSP8, and DSP9 were made on top of loess layers extending over more than $40 \mathrm{~m}$ in depth. On SRT profiles, DSP1 and DSP6, loess layers with a thickness of $5-10 \mathrm{~m}$ can be outlined.

The next layer, $1250<\mathrm{Vp}<2500 \mathrm{~m} / \mathrm{s}$, has a thickness between 10 and $15 \mathrm{~m}$ on profiles DSP3, DSP4, DSP5, DSP8, and DSP9, while on profiles DSP1 (north) and DSP6 (southeast) the thickness of this layer was $30 \mathrm{~m}$ and more (Figure 6). This layer can be defined as the thickness of gravel deposits with boulders, which is supported by existing the borehole data (Figure 3).

Additionally, on these profiles DSP5, DSP6, and DSP9, we could observe at larger depth a velocity of $2500<\mathrm{Vp}<4000 \mathrm{~m} / \mathrm{s}$ with a thickness between 5 and $10 \mathrm{~m}$. This layer is most likely made of conglomerate rocks. On the other hand, in the northern part of the city, the DSP1 profile shows a relatively large skewed layer, marked $2500<\mathrm{Vp}<4000 \mathrm{~m} / \mathrm{s}$, 
which approached the top layer of the SRT profile had a thickness between 10 and $35 \mathrm{~m}$. According to the geology of the northern region, where the Varzob Mountain Range begins, this P-wave velocity of the DSP1 profile represents a sandstone layer (Figure 6).

\subsection{Results of the Horizontal to Vertical Spectral Ratio (HVSR) Measurements from Mobile Seismic Stations}

The analysis of the HVSR ambient noise data was conducted using the Geopsy software (Available online: http:/ / www.geopsy.org/download/archives/geopsypack-src-3. 3.3.tar.gz (accessed on 20 October 2019); [68]). In this analysis, the signal from the ambient noise measurement is represented by the signal amplitude of the three components recorded over time. Each signal component is then subdivided into a series of time windows with a length of 8-30 s. The Fourier spectra amplitudes of the three components were subsequently computed and smoothed smoothing parameter of 40 by the Konno and Ohmachi [69] function.

The data were analyzed over a frequency range of $0.5-25 \mathrm{~Hz}$ and the measured $\mathrm{HV}$ peaks were identified following the recommended criteria for clarity and reliability in accordance with the SESAME project [47].

A total of 175 ambient noise measurements were analyzed, and for each of them the HVSR with fundamental resonance frequency $\left(\mathrm{f}_{0}\right)$ and peak amplitude $\left(\mathrm{A}_{0}\right)$ were obtained. The second or third peaks were designated as $f_{1}$ and $f_{2}$ and amplitude $A_{1}$ and $A_{2}$, respectively. The fundamental resonance frequency $\left(f_{0}\right)$ observed by HVSR curves corresponded to the geological characteristics of the subsurface layer $[40,45,70,71]$. Therefore, the peak frequency is an important indicator of the interface of geological features and layers.

From 175 measurement points, we obtained 90 curves with a clear single peak, 26 curves with multiple peaks, and 14 curves with double peaks. We also identified 45 flat peaks associated with gravel deposits in Southern and Southwestern Dushanbe. Comparing the HVSR peaks with geological and borehole data revealed the consistency of the peaks with the soil layers.

A high frequency peak $(10.8 \mathrm{~Hz})$ was observed in the northern part of the city, suggesting a very thin layer of soft sediment laying over the hard rocks (Figure 7(D50)). On the northwest part of the city, similar high frequency peak $(8-10 \mathrm{~Hz})$ was also encountered on alluvial deposits, which were made of gravel of varying degrees of compaction (Figure 7(D52)). Both of the measurement points D50 and D52 had their loess layer close to the surface at depths of 10-12 m depth.

The HVSR results show that D111 and D61 had a clear peak in range of $1 \mathrm{~Hz}$ and 1.5 Hz (Figure 7(D61,D111)), which corresponded to the depth of the loess layer, which we could also observe in the lithological settings map. According to the map D111 was located at adyr hills where the depth of the loess was above $40 \mathrm{~m}$ and D61 was located at the foot of the hill where the depth of the loess was up to $40 \mathrm{~m}$. Both D76 and D146 curves had flat curve with low amplitude spectra without clearly identified peak. In the map they correspond to the south and south-west sites in the base of the city that shows clearly a rock response of alluvial deposits that were made of conglomerate and gravel materials (Figure 7(D76,D146)).

The north-western part of the city shows a high amplitude peak at frequencies varying from 2 to $4 \mathrm{~Hz}$ (Figure 7(D69,D73)). The differences of the $\mathrm{f}_{0}$ and $\mathrm{A}_{0}$ of D69 and D73 could be linked to the variable thickness of loess sediments, which in case of the D69 was located at the depth of $35 \mathrm{~m}$ and for D73 had a depth from 25 to $15 \mathrm{~m}$. Both of these HVSR results had a clear peak. The upper quaternary and recent deposits alluvial gravels, conglomerates, loess were characterized by intermediate fundamental frequencies $(6-17 \mathrm{~Hz})$ and lower amplitude with an almost flat curve (seen example in Figure 7(D78,D146)). As the amplitude often remained below 2, the peak amplitude rarely fulfilled the SESAME [47] reliability criterion. 

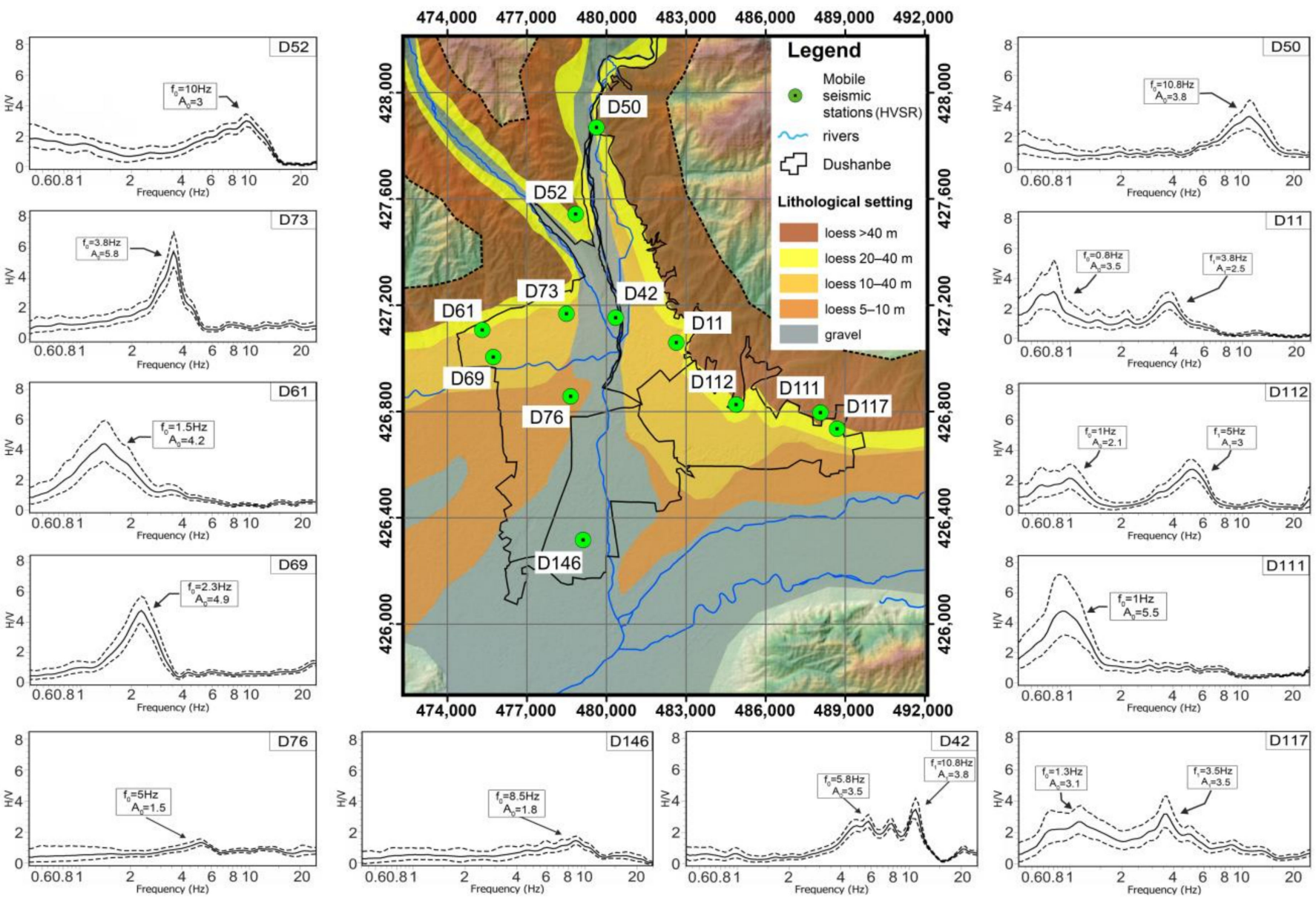

Figure 7. Selected examples of horizontal to vertical spectral ratios (HVSRs) curves showing clear peak (D50, D52, D61, D69, D73, and D111), double peak (D11 and D112) and multiple peaks (D42 and D117) with examples of flat HVSR curves that show a small peak (D76 and D146). The HVSR plot is represented by a thick black continuous line as the averaged HVSR curve, black dashed lines as HVSR standard deviation (std), its associated peak amplitude HVSR $\left(\mathrm{A}_{0}\right)$ with std, $\mathrm{f}_{1}$ as secondary peak frequency of amplitude.

Multiple HVSR peaks were often observed in urban areas, where the local lateral variations due to complex subsurface formations cause peak broadening (Figure 7(D117)) or multiple peaks (Figure 7(D42)) due to Rayleigh wave refraction [17].

HVSR curves with double peaks (Figure 7(D11,D112)) on the north-east and east site of the city at the proximity of the adyr hills corresponded to the multiple layers due to the delluvial terrain. The first peak with a frequency range of $0.8-1 \mathrm{~Hz}$ was the fundamental frequency $\mathrm{f}_{0}$, which was supported by HVSR peaks from other measurement points on the adyr hills. The second peak $f_{1}$ with a frequency range of $4-5 \mathrm{~Hz}$ was suggested to be the delluvial terrain, as indicated by the lithological settings.

In Figure 8, the HVSR results are represented through a combined form of lozenge shape: the frequency value is marked by the color of the lozenge, the associated amplitude by its size and the preferred azimuth of the shaking by the orientation of the long diagonal. The 1D-measurements with clear double frequency peaks are displayed as super-imposed lozenges (the peak of smaller amplitude being on top). 

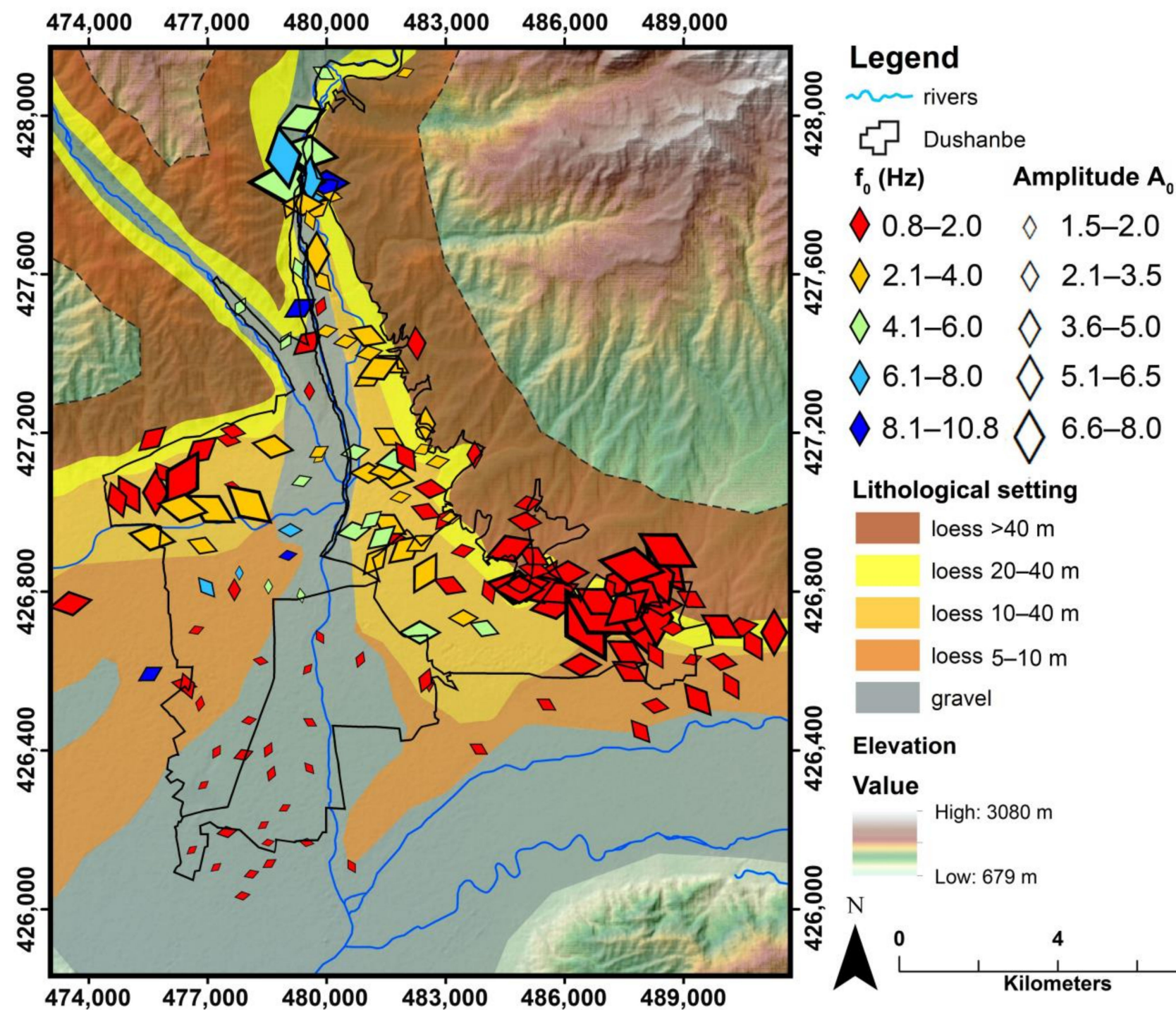

Lithological setting

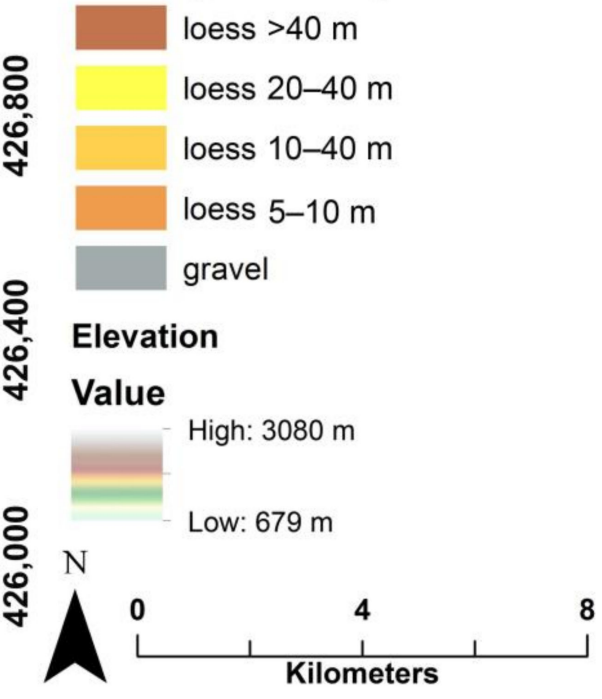

Figure 8. Results of the horizontal to vertical spectral ratios (HVSRs) analyses. Colors of lozenges indicate five different classes of fundamental frequency $\left(\mathrm{f}_{0}\right)$, the sizes of lozenges show the peak amplitudes $\left(\mathrm{A}_{0}\right)$, and the orientation of the long diagonals represents the azimuths.

\subsection{Results of the Microtremor Array Measurements (MAMs)}

In September 2019, five MAM measurements using five seismic stations, which were installed in various parts of Dushanbe (see locations in Figure 9) to obtain information on local shear-wave velocity patterns.

Seismic noise from surface measurements consists of surface waves, and the inversion of the Rayleigh dispersion curve represents the shear wave velocity profile. Only the vertical components of ambient noise recordings were used in the calculations. The records were prepared for instrumental processing, taking into account the calibration parameters of each sensor, and the results were analyzed using SPAC analysis and inverted by using a neighborhood algorithm [72]. The models obtained from the inversion of dispersion curves show shear wave velocities from 0 to $80 \mathrm{~m}$ (Figure 9).

Supported by lithological evidence, the Vs of $200-250 \mathrm{~m} / \mathrm{s}$ obtained at DA5 in the top $45 \mathrm{~m}$ suggests the presence of loess materials (Figure 9, map). Furthermore, we observe that Vs increased from 250 to $450 \mathrm{~m} / \mathrm{s}$, which defines the compact layer of the gravel at depths of $45-80 \mathrm{~m}$. 

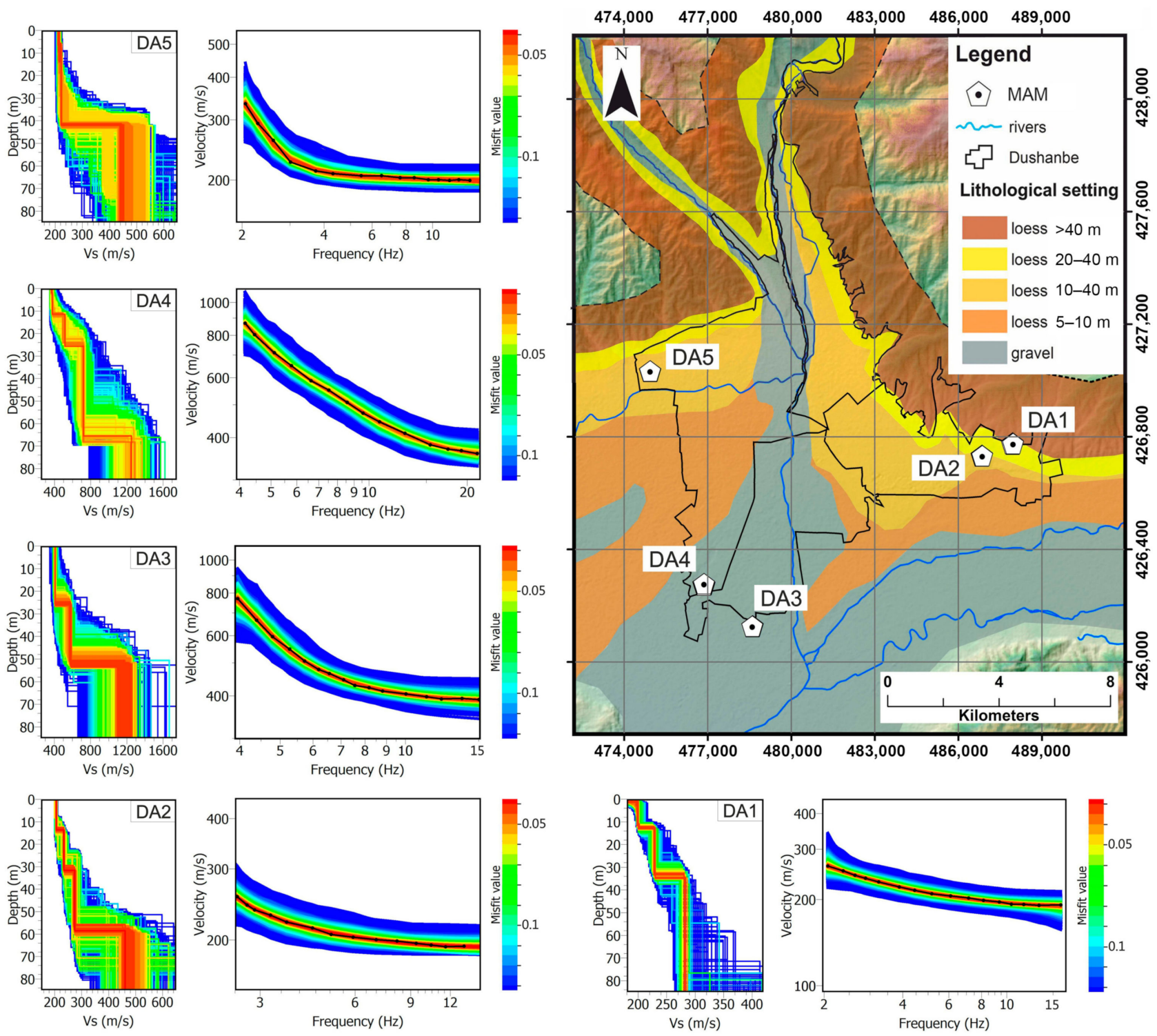

Figure 9. Inversion results of five microtremor array measurements (MAMs) and dispersion curves (black lines) and theoretical curves corresponding to the tested models (color indicates the misfit value). Shear-wave velocity models for each tested site. The best model achieved is highlighted in red.

For the DA4 array, we observe an onset of Vs $400 \mathrm{~m} / \mathrm{s}$ on the uppermost layer, which increased to $550 \mathrm{~m} / \mathrm{s}$ up to $25 \mathrm{~m}$ depth. This velocity at the beginning may refer to the mixed loess and gravel layer, which then increased, going deep into the gravel layer. The second shear wave velocity profile of $550-700 \mathrm{~m} / \mathrm{s}$ at depths from 25 to $65 \mathrm{~m}$ indicates the gravel layer with a higher degree of compaction. Further, at a depth of $65-80 \mathrm{~m}$, the velocity profile accelerated from 700 to $1250 \mathrm{~m} / \mathrm{s}$, which may indicate the presence of bedrock (conglomerate or sandstone).

In the case of the DA3 array, which is also located on gravel deposits, up to a depth of $25 \mathrm{~m}$ there is a shear-wave velocity profile of $420 \mathrm{~m} / \mathrm{s}$. In addition, when moving deeper, the velocity profile gets higher from 420 to $600 \mathrm{~m} / \mathrm{s}$ at depths of $25-55 \mathrm{~m}$, which suggests a higher degree of compaction of gravel. At the depth above 55-80 m the shear wave velocity Vs gets up to $1200 \mathrm{~m} / \mathrm{s}$, which suggests the presence of sandstone or conglomerate (Figure 9).

DA1 and DA2 arrays were located on the east side of the city and are located on the loess layers. Shear wave profiles of both show similar pattern. At DA2 onset of the Vs 
was at 200-250 m/s up to $35 \mathrm{~m}$ depth. From 35 to $60 \mathrm{~m}$ depth the Vs stayed constantly at $310 \mathrm{~m} / \mathrm{s}$. At a depth above 60-80 m velocity abruptly increased to $480 \mathrm{~m} / \mathrm{s}$, which indicates change of the layer from loess to gravel. A similar low velocity profile (180-240 m/s) was observed at the onset up to $35 \mathrm{~m}$ of depth in the DA1 array. From a 35 to $80 \mathrm{~m}$ depth a constant velocity profile of $280 \mathrm{~m} / \mathrm{s}$ stayed, which suggests a higher degree of compaction of the loess layers (Figure 9).

\subsection{Data Processing of the Earthquake Data}

During the period from August 2019 to January 2020 in total 15 earthquakes with magnitude $2.0<\mathrm{M}<5.3$ were registered at five temporary seismic stations in the city and at one permanent seismic station (Figure 3) and analyzed with the use of the Geopsy software by [68].

For the higher signal amplitudes and longer duration, we selected 5 over the 15 events with $\mathrm{M}$ ranging from 4.0 to 5.3 and with epicentral distance between 30 and $150 \mathrm{~km}$ (estimated using the SeisComp3 software). Table 5 presents a list of all events detected during the registration period. An example of the earthquake of 15 October 2019 at 4:20:20 pm (UTC) with the epicenter of the $M=4.0$ was $30 \mathrm{~km}$ southeast from Dushanbe at the station BAZ (east part of the Dushanbe), and at reference station, DZET is shown in Figure 10. The comparison of both recordings shows that the BAZ station was affected by larger shaking amplitude (here, the amplitude scales are the same for all recordings) than the DZET station, which was actually on the bedrock. Seismogram analysis at the other four stations of the same event shows that BAU and BB2 stations registered higher amplitudes and longer durations than the stations BB0 and BAV (see Figure A1 in the Appendix A). Each seismogram provides data of three components.

Table 5. List of the five earthquakes used for the standard spectral ratio (SSR) calculations. Epicenters had a maximum distance of $150 \mathrm{~km}$ to Dushanbe.

\begin{tabular}{cccccccc}
\hline Year & Month & Data & Time (UTC) & Latitude & Longitude & Magnitude & Depth (km) \\
\hline 2019 & 9 & 3 & $4: 34: 35$ PM & 38.9476 & 70.533 & 4.2 & 12 \\
2019 & 9 & 21 & $11: 30: 58$ AM & 38.6512 & 70.1729 & 4.6 & 21 \\
2019 & 10 & 15 & $4: 20: 20$ PM & 38.3132 & 68.9488 & 4.0 & 10 \\
2019 & 11 & 12 & $2: 01: 49$ PM & 37.7933 & 69.9641 & 4.3 & 10 \\
2020 & 1 & 29 & $9: 10: 46$ AM & 38.8107 & 70.5587 & 5.3 & 10 \\
\hline
\end{tabular}

The standard spectral ratio method (SSR, see, e.g., [10,22-25,67]) involves the comparison of earthquake recordings from nearby sites, using one of them as a reference. As a result, the standard spectral ratio can directly demonstrate the site effect. Reference site choice is generally made with the consideration of seismic velocities and characteristic amplitudes of the different sites. Djerino (DZET), a permanent station located on outcrops of Paleozoic rocks (granite) about $14 \mathrm{~km}$ north of Dushanbe, was used as a reference station to calculate the SSR based on its use as a reference site in previous studies of the city [10].

In order to calculate the SSR curves of the five preselected earthquakes, S-wave windows extracted and a Fourier amplitude spectrum (FAS) was calculated for each of the components. Only the north-south and east-west components were selected to estimate the SSR curve, and each of them was divided by the corresponding component from the reference station (DZET) calculated in a similar way. The resulting SSR curves are illustrated in Figure 11a1-e1. In addition, the squared mean $\left(\mathrm{H}_{\mathrm{avg}}\right)$ was calculated for all horizontal components of the station. 
Seismic event 2019-10-15T04:20:20

Southeast from Dushanbe: Lat 38.3132 Lon 68.9488; $M w=4.0 ; H=10 \mathrm{~km}$
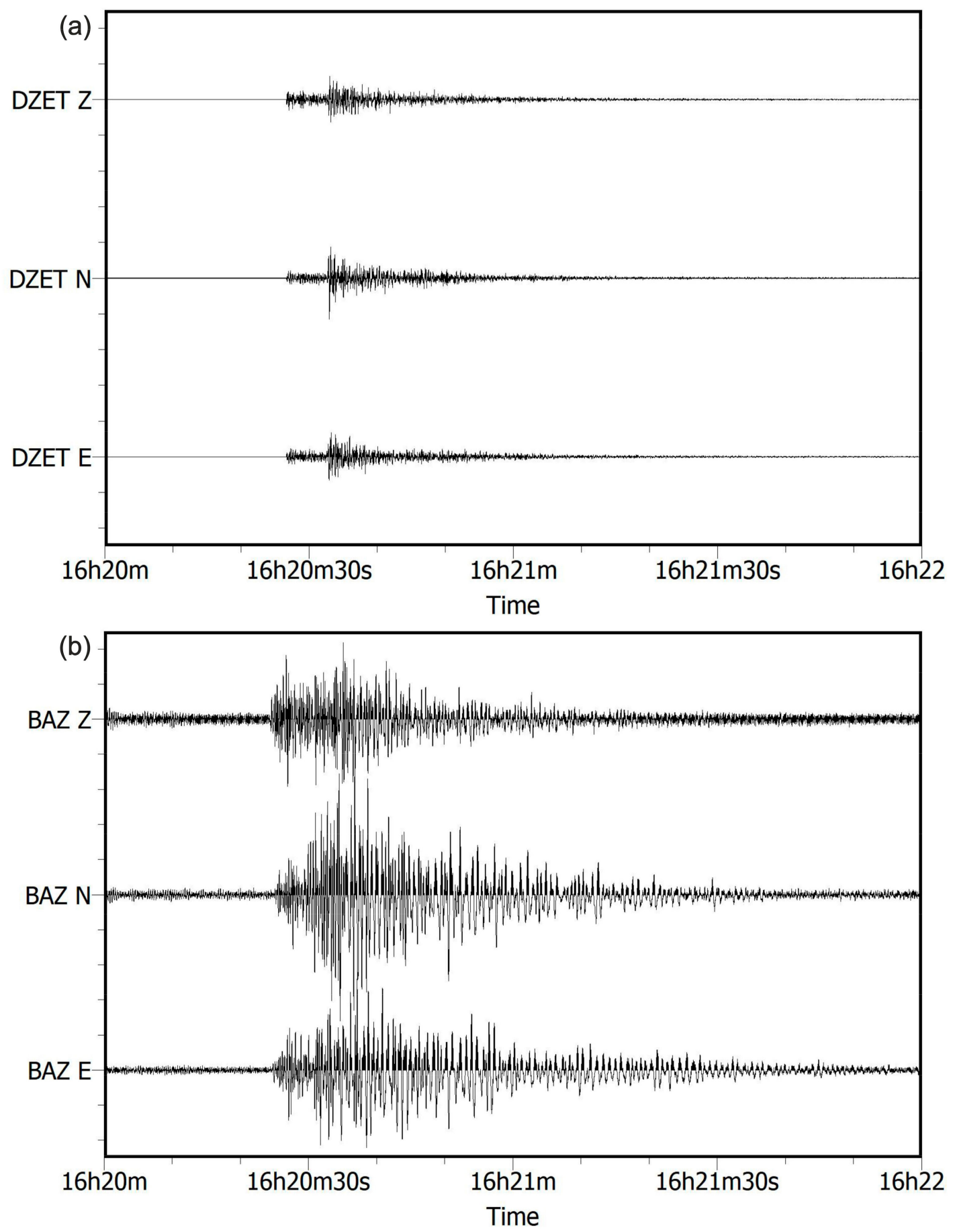

Figure 10. Examples of triaxial seismograms (E for E-W, N for N-S, and Z for vertical) for one of the five events recorded at reference station DZET (a); on rock and BAZ (b); on loess. The epicenter of the 4.0 event is $30 \mathrm{~km}$ southeast from Dushanbe. Amplitude scales are the same for all records.

In addition, we calculated the HVSR earthquake curves (EHVSR; Figure 11(a2-e2)) for each station, and the HVSR curves for each station not covering the earthquake period, which represent the HVSR noise (NHVSR; Figure 11(a3-e3)) data. For EHVSR, the S-wave windows were taken from seismograms with a 5\% taper and window length selected consistently with the S-wave signals' maximum time duration. 

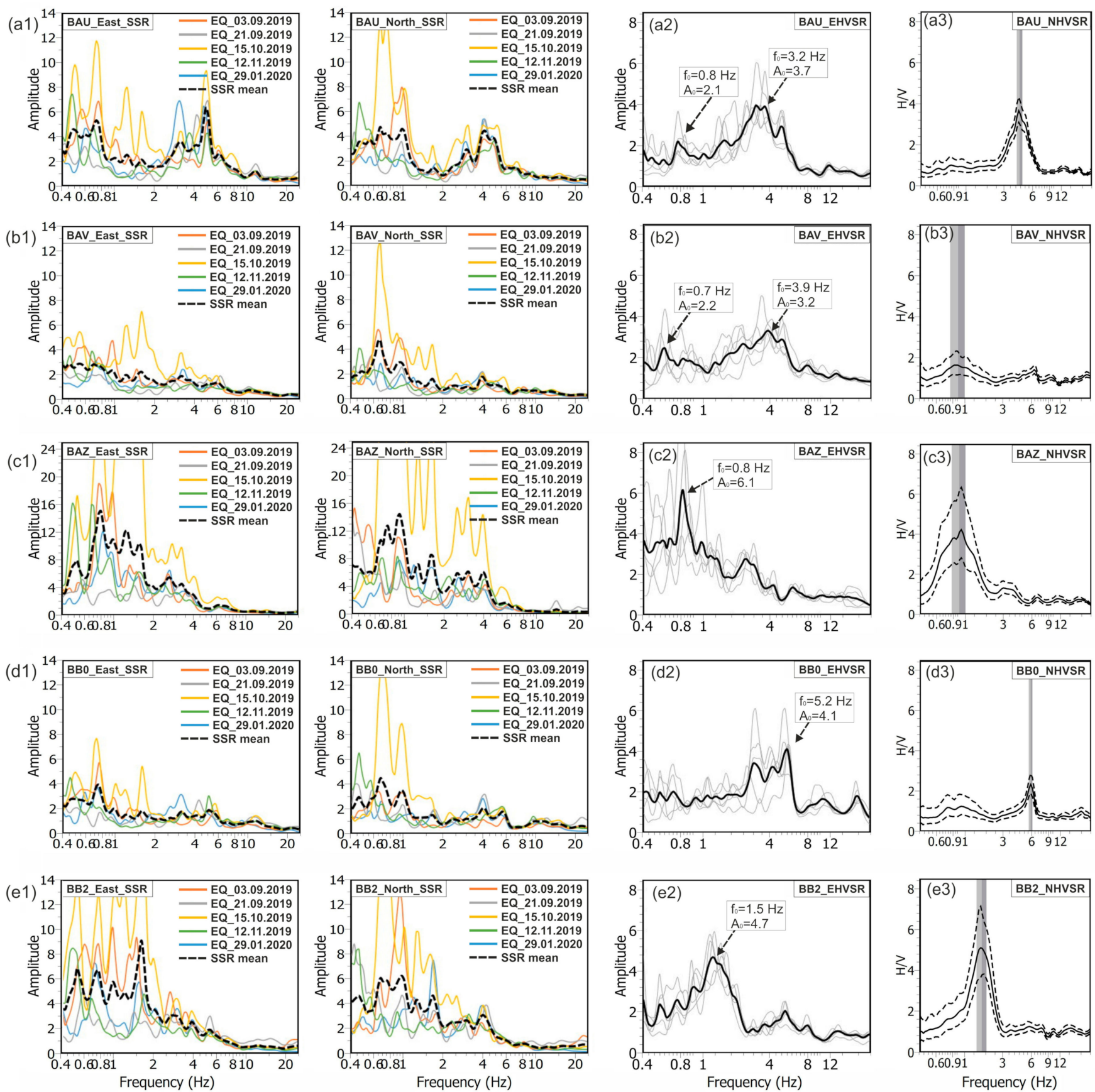

Figure 11. The SSR calculated for the S-wave window (a1-e1) from five selected earthquakes for the east-west and northsouth components at each station and the corresponding spectrum at the DZET (reference station). In addition, (a2-e2) show the HVSR earthquake (EHVSR) curves and (a3-e3) show the HVSR noise (NHVSR) curves from each station. In all figures, the black dashed curve shows the average SSR for the east-west and north-south components for five selected earthquakes. Please note the different amplitude range variation for the station BAZ (c1).

\subsection{The Standard Spectral Ratio (SSR) and S-Waves Results}

The BAU station data (Figure 11(a1-a3)) show similar patterns of peak activity in the range from 0.5 to $1 \mathrm{~Hz}$ and second more prominent peak from about 3 to $6 \mathrm{~Hz}$ with an amplitude of 4-6 for the earthquake data (SSR for the E and N components, EHVSR). In addition, a small bump can be observed at the lower frequency range of $0.5-1 \mathrm{~Hz}$ in the NHVSR data and clear peak at $4-4.5 \mathrm{~Hz}$. The peak activity at lower frequencies in the SSR and EHVSR curves can be explained by the resonance effect, which may arise from a 
deeper, more compact layer that can be bedrock (conglomerate or sandstone) and result from $S$-waves propagating from the earthquake source.

The BAV station is located on gravel, which can be also confirmed in SSR and EHVSR curves by the absence of the peak at the higher frequencies, which was clearly seen in the SSR and EHVSR curves of the BAU station that is located on a layer of loess (Figure 3). In addition, HVSR peaks from measurement points around the station all show flat curves with a bump at lower frequencies $(0.8-2 \mathrm{~Hz})$ which support that BAU station is located on the more compact gravel layer (Figure 3). In the SSR curves of the BAV station we do not observe clear peaks at higher frequencies that are present in the EHVSR curve with a higher amplitude peak. At lower frequencies we observe a peak with high amplitude only on the north component of the SSR (Figure 11(b1-b3)). The EHVSR curves of the BAV and BAU stations both show similar peak activity, which may be due to the same underlying bedrock structure going through both stations. This suggestion can also be supported by the presence of the peak activity at low frequencies of HVSR at the BAV station and only a low amplitude bump at the same frequencies in the BAU station.

The BAZ station is located on the thick layer of loess and contains multiple peaks at lower frequencies $(0.4-1 \mathrm{~Hz})$ for both north and east SSR curves, EHVSR and NHVSR curves. A similar pattern can be observed from the measurement points of the mobile station HVSR analysis in the proximity of the station (see Figure A2 in the Appendix A). The HVSR peaks around the stations have multiple and single peaks at low frequencies $(0.8-2 \mathrm{~Hz})$. SSR curves of north and east components show multiple peaks at lower frequencies ranging from 0.4 to $2 \mathrm{~Hz}$ with high amplitudes from 8 to 15. At a frequency range of $2-4 \mathrm{~Hz}$ there are observable peaks with lower amplitudes in East SSR, North SSR, EHVSR, and as a bump in the NHVSR. In the NHVSR curve a clear narrow peak at $0.9 \mathrm{~Hz}$ can be seen. Peak activity that can be observed in SSR curves and EHVSR at 2-4 Hz can suggest that layer at this range has higher degree of compaction (Figure 11(c1-c3)).

Similarly, station BB2, located on the opposite side from station BAZ, is also located on the loess layer (Figure 3). A clear peak of activity can be observed at $1.5 \mathrm{~Hz}$ with amplitude 5 in the NHVSR curve, which also supports the presence of a thick loess layer. Comparison with borehole data in the vicinity of the station can show that the loess layer is $40-45 \mathrm{~m}$ thick and even thicker near the adyr hills and includes layers of underlying gravel. Therefore, a similar pattern with multiple peaks at lower frequencies $(0.5-2 \mathrm{~Hz})$ but with lower amplitudes (6-9 East SSR; 5-6 North SSR) can be observed for the SSR curves. The EHVSR curve shows a clear peak at $1.5 \mathrm{~Hz}$ with amplitude 4-5 (Figure 11(e1-e3)).

Station BB0 is located on a thin layer of loess $(5-10 \mathrm{~m})$ overlying a gravel layer (Figure 3). Therefore, it shows a similar peak pattern with the BAV station, which is also located on gravel. The SSR curves show low amplitude peaks at a frequency range of $0.6-1 \mathrm{~Hz}$ with an amplitude ranging from 2 to 4 . In addition, a slight increase of amplitude over the frequency range of $4-6 \mathrm{~Hz}$ can be observed in the SSR curves, which was amplified in the EHVSR curve with amplitude from 3 to 6 . In the NHVSR curve a small narrow peak at $6 \mathrm{~Hz}$ with amplitude 2.5 demonstrates that it is located on the thin loess layer (Figure 11(d1-d3)). A comparison with borehole data and cross sections in the proximity of the station confirms the presence of the thin upper loess layer, gravel, and conglomerate layers (Figure 3).

\section{Discussion}

A geophysical-seismological and geological survey was completed in order to characterize the near-surface layers and related site effect potential of Dushanbe city and surrounding areas in Tajikistan.

The results of the present analysis based on geological and seismological data, including borehole logs, cross-sections, HVSR, SRT, MAM, and SSR measurements revealed four distinguishable layers of soil in the area-loess, gravel, conglomerate, and sandstone (bedrock), which were obtained from the areas surrounding the city from the northwest, 
east, southwest, and southeast. The summarized results and findings for each region are discussed in detail below.

\subsection{North and Northwest Territories of Dushanbe City}

The P-wave velocities obtained by the SRT method for the northern DSP1 site (within the valley) quickly increase with a depth up to $4000 \mathrm{~m} / \mathrm{s}$ on the north side but remain quite low in the southern part, thus indicating a steep south-dipping bedrock surface at depth (Figure 6). DSP2, DSP3, and DSP4 profiles, which had all been completed in the northwestern zone, all show the same pattern with a lower P-wave velocity near the surface due to the dominance of the loess layer, which is also confirmed by the borehole data. This P-wave velocity only increases at a larger depth $(>30 \mathrm{~m})$, where the loess is replaced by gravel. In addition, shear wave velocities obtained from the MAM confirm this pattern (Figure 9(DA5)) by lower Vs in the upper layers related to the loess (from 0 to $45 \mathrm{~m}$ depth) and Vs increased below $45 \mathrm{~m}$, suggesting the presence of gravel underlain by bedrock at a depth of $80 \mathrm{~m}$.

Site response data obtained from the seismic station BB2 located in the northwestern zone are all marked by a high amplification factor due to the contrast of impedance between the loess and the underlying gravel layers (confirmed by nearby borehole information). This is supported by HVSR measurements from mobile stations located near the station, which showed clear peaks at frequencies of 1-2 Hz (see Figure A2 in the Appendix A, ex: D60, D63). EHVSR curves and NHVSR from the station also show a clear peak in this frequency range. Therefore, the site effects measured in the northwestern zone are expected to be high.

\subsection{West and Southwest Side of Dushanbe City}

P-wave velocity profiles from DSP5 (located on the west from the BAV station) show the transition from lower velocities (750-1250 m/s) in the upper layer (10-15 m, possibly made of loess) to larger $V_{p}$ of $2250 \mathrm{~m} / \mathrm{s}$ at a depth of $20 \mathrm{~m}$ to $3500 \mathrm{~m} / \mathrm{s}$ at a depth of $50 \mathrm{~m}$ (Figure 6). The first increase of $\mathrm{V}_{\mathrm{p}}$ was related to the gravel's presence and the second layer of the conglomerate. This is confirmed by the cross-section data from southwest to the northeast in Figure 6.

Results of DA4 and DA3 arrays, located on gravel, distinguish two groups of soil layers according to Vs profiles, with an upper layer Vs of $400-700 \mathrm{~m} / \mathrm{s}$ indicating the presence of soft rock and a deeper layer with Vs 1200-1250 m/s representing the harder rock. In the case of DA4, Vs with 1200-1250 m/s starts at a depth of $65 \mathrm{~m}$, and for DA3, it was found below $55 \mathrm{~m}$ (Figure 9(DA3,DA4)). This deepening of the top of the conglomerate in the southwestern direction can also be confirmed by the cross-section data in that zone (Figure 3c).

Site response data from the BAV (southwest) and BB0 (west) stations show very low susceptibility to site amplification. HVSR curves from stations and HVSR curves obtained from the mobile stations in the proximity of those stations all show flat curves characteristic of a low impedance contrast in the subsurface (see Figure A2 in the Appendix A, ex: D62, D54). At both stations, N-S SSRs show slightly higher site amplification potential within a frequency range of $0.6-1 \mathrm{~Hz}$, marked by amplitudes of 3-5. The NHVSR curve shows a narrow peak at $6 \mathrm{~Hz}$ with an amplitude of 2, which may be due to a thin layer of loess (5-10 m). However, the BAV station did not show any peak within this frequency range. Within the lower frequency range of $0.6-1 \mathrm{~Hz}$, a clear peak is present in both stations NHVSR curves (Figure 11(b1-b3,d1-d3)).

\subsection{East and North-East of Dushanbe City}

P-wave velocity profiles of DSP7, DSP8, and DSP9 located on the east side of the city all show predominantly low $\mathrm{V}_{\mathrm{p}}(500-750 \mathrm{~m} / \mathrm{s})$ down to a depth of 30-40 m; $\mathrm{V}_{\mathrm{p}}$ close to $1250 \mathrm{~m} / \mathrm{s}$ was only reached at a depth of $50 \mathrm{~m}$ for DSP7, and $30 \mathrm{~m}$ for DSP8 and DSP9 (Figure 6). On DSP9, at a depth of 50-60 m, the high $V_{p}$ of 2500-3500 m/s suggests the 
presence of the gravel layer at this depth. According to the P-wave data, the uppermost layer consists of loess. The same soft uppermost layer of loess was suggested by the low shear-wave velocities measured by the MAM (Figure 9(DA1,DA2)).

The two stations BAU and BAZ are located in this area. HVSR measurements near the BAZ station show clear peaks with high amplitude between 0.8 and $2 \mathrm{~Hz}$ (see Figure A2 in the Appendix A, ex: D101, D110), whereas HVSR curves near the BAU station show single peaks at a higher frequency of 2.1-4 Hz (see Figure A2 in the Appendix A, ex: D38, D116). The SSR curves from both stations show peaks within a similar frequency range $(0.8-2 \mathrm{~Hz})$, but with different amplitude, those at BAZ being clearly larger than those at BAU station (Figure(11a1-a3,d1-d2)). This is also supported by lithological settings, which show that the BAZ station was located on a loess layer that was more than $40 \mathrm{~m}$ thick (for BAU, the combined loess and gravel layers could explain the similar amplified frequency range due to a combined larger thickness, but marked by lower amplitudes due to an average larger Vs compared to the pure loess layer in BAZ).

\section{Conclusions}

The specific and validated seismic hazard assessment for the cities with high infrastructure industry and the population is extremely important. Such a task is particularly important for a city such as Dushanbe, as it is located in a region of high seismicity. The morphology and position of the underlying rocks (depth from the surface), covered by different soft sediments with variable thickness, have previously not been studied sufficiently to be able to provide the information for a reliable seismic microzonation of the urban areas. The same is true for the variability affecting the physical properties of the soils, considering their distribution over the whole area and over different depths. This study is the first one to use four modern seismological methods and data processing techniques to clarify the impact of different ground conditions in Dushanbe on seismic actions. Here, the geophysical-seismological data are presented and analyzed with respect to their geological relevance.

In terms of geophysical and seismic data, this study makes a valuable contribution to assessing seismic hazard and vulnerability in this area. The resulting data that we acquired are highly important for the new seismic microzonation of the city, because existing map of microzoning was made in 1975 based mostly on the engineering- geological data. Detailed seismic hazard map for the city can be developed, which then can be used to clarify the seismic actions to the buildings, lifelines, and community planning. Used instrumental methods to define the seismic conditions of the subsurface layers in the Dushanbe city allow one to prepare more accurate and correct seismic microzoning map for improving the aseismic design for new construction in Dushanbe, where the 16- and 20-stores building are the majority of the construction. Additionally, it is clear that the aseismic design of such building must be based on the new methodology and approaches.

An upcoming paper will determine more quantitatively the site effect potential through numerical modeling results; also site effect distribution maps will be presented on the basis of survey and modeling inputs. Thus, these results can be used as inputs for 2D numerical modeling, 3D geomodeling, and will be a basis for further studies, like for the quantitative assessment of seismic impacts on buildings, dams, slopes, and so on.

Author Contributions: Conceptualization, H.-B.H., A.I., and F.H.; Methodology, H.-B.H., A.I. and F.H.; Validation, F.H. and H.-B.H.; Formal Analysis, F.H. and H.-B.H.; Investigation, F.H.; Resources, A.I., and F.H.; Data Curation, F.H. and A.I.; Writing-Original Draft Preparation, F.H.; WritingReview and Editing, A.I., G.D., K.R., L.C. and H.-B.H.; Visualization, F.H. and G.D.; Supervision, H.-B.H., A.I., and K.R. All authors have read and agreed to the published version of the manuscript.

Funding: This research received no external funding.

Institutional Review Board Statement: Not applicable.

Informed Consent Statement: Not applicable. 
Data Availability Statement: Unless specified differently, data and imagery used for this publication are freely available from the following providers or software: ALOS World 3D-30 m (AW3D30)/Credit: JAXA/EORC (Available online: https://www.eorc.jaxa.jp/ALOS/en/aw3d30/ index.htm (accessed on 10 September 2019)); ArcGIS/Credit: Esri (version 10.5.1); GEOPSY/Credit: owner (version 3.3.3. Available online: http:/ / www.geopsy.org/download/archives/geopsypacksrc-3.3.3.tar.gz (accessed on 20 October 2019)); Google Earth Pro/Credit: Google 2020 (version 7.3.3); SRTM 1 Arc-Second Global/Credit: USGS (Available online: https:/ / earthexplorer.usgs.gov (accessed on 7 September 2019)).

Acknowledgments: We are grateful to the editors and two anonymous reviewers for their constructive comments, which significantly improved the manuscript. We express our acknowledgments to the German Academic Exchange Service (DAAD) for financial support for the research project in the RWTH Aachen University in the period 2018-2019. The authors also thank to the Department of Neotectonics and Natural Hazards RWTH Aachen University. We are thankful to the technical staff Umedzhon Sharifov, Bekhruz Alamov, Damir Baygenov, and Nusratulo Sharipov of the Institute of Geology, Earthquake Engineering and Seismology of the Academy of Sciences of the Republic of Tajikistan for their help during the field work. We also thank Makhdi Narzulloev and Yakov Andrushuk of the Southern Geophysical Expedition of the Main Department of Geology under the Government of Tajikistan for their instrumental support with the seismic refraction tomography and measurements. Finally, we thank Pulat Aminzoda, Director of the Institute of Geology, Earthquake Engineering and Seismology of the Academy of Sciences of the Republic of Tajikistan, for support and provided instruments for the microtremor measurements in the city area.

Conflicts of Interest: The authors declare no conflict of interest.

\section{Appendix A}

Seismic event 2019-10-15T04:20:20

Southeast from Dushanbe: Lat 38.3132 Lon 68.9488; $M w=4.0 ; H=10 \mathrm{~km}$

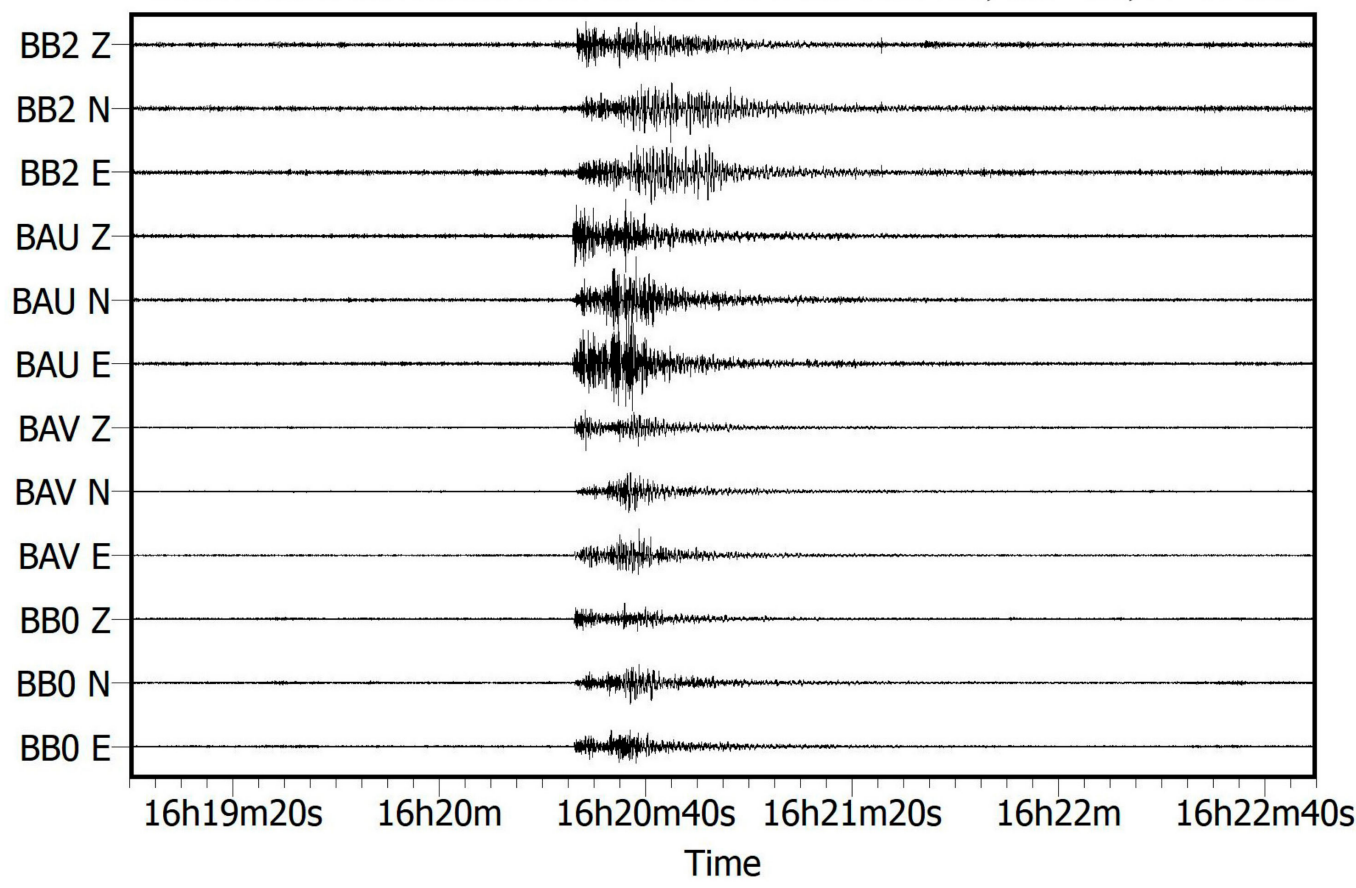

Figure A1. Examples of triaxial seismograms (E for E-W, N for N-S, and Z for vertical) for one of the five events recorded at other four stations (BAU, BB2, BB0, and BAV). The epicenter of the 4.0-event is $30 \mathrm{~km}$ southeast of Dushanbe. 

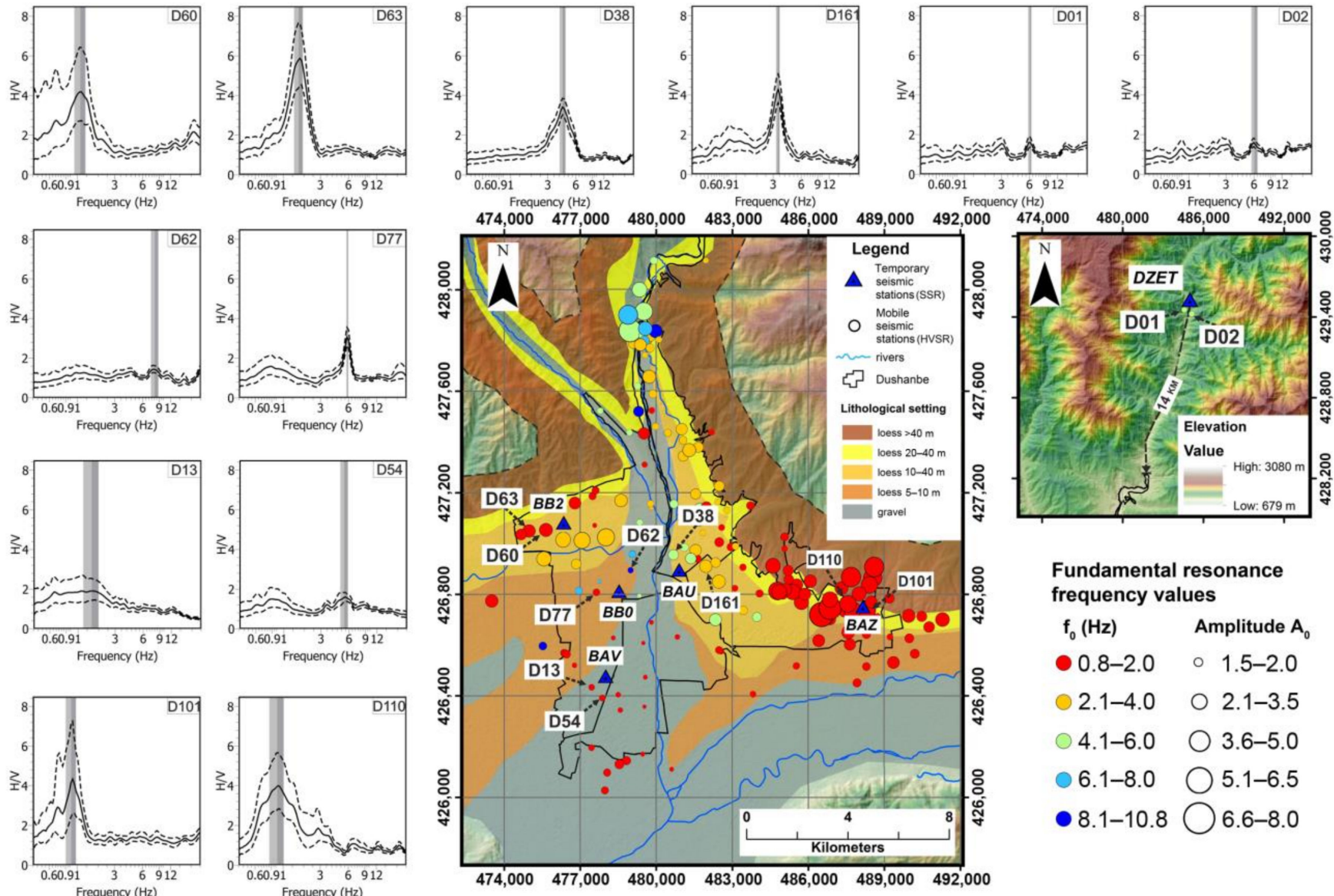

Figure A2. Map of the Dushanbe city showing the locations of the temporal seismic stations for SSR, mobile seismic stations (HVSR), lithological settings, and information about the fundamental resonance frequency and amplitude values. The inlet on the right shows the location of the reference station. Selected HVSR curves from mobile seismic stations near to temporal seismic stations are shown as well.

\section{References}

1. Babaev, A.M.; Ischuk, A.R.; Negmatullaev, S.K. Seismic Conditions of the Territory of Tajikistan; Publication of the International University of Tajikistan: Dushanbe, Tajikistan, 2005; pp. 93-98.

2. Negmatullaev, S.K.; Rodzhan, K.; Lunev, A.A.; Zolotarev, A.I. Strong Motion Service of Tajikistan; Donish: Dushanbe, Tajikistan, 1987; p. 150. (In Russian)

3. Katok, A.P. The Khait Earthquake of 1949 July 10: Effect on Regime of Dushanbe and Garm; Academy Science USSR: Dushanbe, Tajukistan, 1965; pp. 8-14. (In Russian)

4. Medvedev, S.; Sponheuer, W.; Karník, V. Neue seismische Skala Intensity Scale of Earthquakes, 7. Tagung der Europäischen Seismologischen Kommission vom 24. 9. bis 30. 9. 1962 in Jena, DDR; Akademie-Verlag: Berlin, Germany, 1964; pp. 69-76.

5. Ishihara, K.; Okusa, S.; Oyagi, N.; Ischuk, A. Liquefaction induced flow slide in the collapsible loess deposit in Soviet Tajik. Soils Found. 1990, 30, 73-89. [CrossRef]

6. Nechaev, V.A. Seismic Microzonation of Stalinabad Territory on the Basis of Instrumental-Geological Method; Academy Science, USSR: Dushanbe, Tajikistan, 1959; pp. 22-35. (In Russian)

7. Bune, V.I.; Gorshkov, G.P. Seismic Zonation of USSR; Nauka: Moscow, Russia, 1980; p. 307. (In Russian)

8. Babaev, A.M.; Koshlakov, G.V.; Mirzoev, K.M. Seismic zonation of the area of Tajikistan; Donish: Dushanbe, Tajikistan, 1978; pp. 60-68. (In Russian)

9. Bindi, D.; Abdrakhmatov, K.; Parolai, S.; Mucciarelli, M.; Grünthal, G.; Ischuk, A.; Mikhailova, N.; Zschau, J. Seismic hazard assessment in Central Asia: Outcomes from a site approach. Soil Dyn. Earthq. Eng. 2012, 37, 84-91. [CrossRef]

10. Pilz, M.; Bindi, D.; Boxberger, T.; Hakimov, F.; Moldobekov, B.; Murodkulov, S.; Orunbaev, S.; Pittore, M.; Stankiewicz, J.; Ullah, S.; et al. First Steps toward a Reassessment of the Seismic Risk of the City of Dushanbe (Tajikistan). Seismol. Res. Lett. 2013, 84, 1026-1038. [CrossRef]

11. Rafi, Z.; Lindholm, C.; Bungum, H. Probabilistic seismic hazard of Pakistan, Azad-Jammu and Kashmir. Nat. Hazards 2012, 61, 1317-1354. [CrossRef]

12. Giardini, D.; Grunthal, G.; Shedlock, K.; Zheng, P. The GSHAP Global Seismic Hazard Map. Annali di Geofisica 1999, 42, 1225-1230. 
13. Zheng, P.; Yang, Z.; Gupta, H.; Bhatia, S.; Shedlock, K. Global Seismic Hazard Assessment Program (GSHAP) in continental Asia. Ann. Geophys. 1999, 42, 1167-1190.

14. Ischuk, A.; Bjerrum, L.W.; Kamchybekov, M.; Abdrakhmatov, K.; Lindholm, C. Probabilistic Seismic Hazard Assessment for the area of Kyrgyzstan, Tajikistan, and Eastern Uzbekistan, Central Asia. Bull. Seismol. Soc. Am. 2017, 108, 130-144. [CrossRef]

15. D'Amico, V.; Picozzi, M.; Baliva, F.; Albarello, D. Ambient noise measurements for preliminary site-effects characterization in the urban area of Florence, Italy. Bull. Seismol. Soc. Am. 2008, 98, 1373-1388. [CrossRef]

16. Bonnefoy-Claudet, S.; Cotton, F.; Bard, P.-Y. The nature of noise wave field and its applications for site effects studies: A literature review. Earth Sci. Rev. 2006, 79, 205-227. [CrossRef]

17. Bonnefoy-Claudet, S.; Baize, S.; Bonilla, L.F.; Berge-Thierry, C.; Pasten, C.R.; Campos, J.; Volant, P.; Verdugo, R. Site effect evaluation in the basin of Santiago de Chile using ambient noise measurements. Geophys. J. Int. 2009, 176, 925-937. [CrossRef]

18. Domej, G.; Aslanov, U.; Ischuk, A. Geophysical investigations on the contribution of irrigation channels to landslide activity in Tusion, Tajikistan. J. Himal. Earth Sci. 2019, 52, 161-177.

19. Guéguen, P.; Cornou, C.; Garambois, S.; Banton, J. On the Limitation of the H/V Spectral Ratio Using Seismic Noise as an Exploration Tool: Application to the Grenoble Valley (France), a Small Apex Ratio Basin. Pure. Appl. Geophys. 2007, 164, 115-134. [CrossRef]

20. Havenith, H.-B.; Fäh, D.; Polom, U.; Roullé, A. S-wave velocity measurements applied to the seismic microzonation of Basel, Upper Rhine Graben. Geophys. J. Int. 2007, 170, 346-358. [CrossRef]

21. Havenith, H.-B.; Umaraliev, R.; Dudnikov, A. Seismic zonation map of Osh, Kyrgyz Republic. In Cross Border Community Based Disaster Preparedness and Risk Mitigation for Vulnerable Rural Populations of the Ferghana Valley; ECHO Project Report; ACTED-Agency for Technical Cooperation and Development: Bishkek, Kyrgyzstan, 2009.

22. Parolai, S.; Bindi, D.; Augliera, P. Application of the generalized inversion technique (GIT) to a microzonation study: Numerical simulations and comparison with different site-estimation techniques. Bull. Seism. Soc. Am. 2000, 90, 286-297. [CrossRef]

23. Parolai, S.; Orunbaev, S.; Bindi, D.; Strollo, A.; Usupaev, S.; Picozzi, M.; Di Giacomo, D.; Augliera, P.; D’Alema, E.; Milkereit, C.; et al. Site Effects Assessment in Bishkek (Kyrgyzstan) Using Earthquake and Noise Recording Data. Bull. Seismol. Soc. Am. 2010, 100, 3068-3082. [CrossRef]

24. Pilz, M.; Parolai, S.; Leyton, F.; Campos, J.; Zschau, J. A comparison of site response techniques using earthquake data and ambient seismic noise analysis in the large urban areas of Santiago de Chile. Geophys. J. Int. 2009, 178, 713-728. [CrossRef]

25. Pilz, M.; Abakanov, T.; Bindi, D.; Boxberger, T.; Moldobekov, B.; Orunbaev, S.; Silacheva, N.; Ullah, S.; Usupaev, S.; Yasunov, P.; et al. An overview on the seismic microzonation and site effect studies in Central Asia. Ann. Geophys. Italy 2015, 58, 104-116. [CrossRef]

26. Ulysse, S.; Boisson, D.; Prépetit, C.; Havenith, H.B. Site Effect Assessment of the Gros-Morne Hill Area in Port-au-Prince, Haiti, Part A: Geophysical-Seismological Survey Results. Geosciences 2018, 8, 142. [CrossRef]

27. Head Institute of Engineering and Technical Surveys of the State Construction Committee of Tajikistan (HIETSCCT). Collection of borehole data from the Dushanbe city area. Personal communication, 2019.

28. Zolotarev, G.S.; Fachorenko, W.S.; Lipmija, W.I.; Hergow, D.; Rohdijow, N.A.; Jaodokowa, P. Polygon-Based Engineering and Geological Map of the Dushanbe Region; Soviet Academy of Science: Moscow, Russia, 1985; p. 15. (In Russian)

29. Kopilov, A.L. The Map of the Seismic Microzonation of the Dushanbe Area Made Using the Method of Acoustic Stiffness; Quarterly Report; GIINTIZ Institute: Dushanbe, Tajikistan, 1989; p. 170. (In Russian)

30. Kukhtikov, M.M. Tectonic Zonation and the Most Important Regularities of the Structure and Development of Gissaro-Alai in Paleozoic; Donish: Dushanbe, Tajikistan, 1968; pp. 34-43. (In Russian)

31. Bekker, Y.; Koshlakov, G.; Kuznetsov, E. On Tectonics of Dushanbe Region (Hissar Valley) Based on the Results of Geological and Geophysical Research on Prognostic Test Sites; Nauka: Moscow, Russia, 1974; pp. 24-29. (In Russian)

32. Babaev, A.M.; Lyskov, L. The Newest Tectonics of Dushanbe Polygon Area; Nauka: Moscow, Russia, 1985; pp. 29-41. (In Russian)

33. Durkin, A.T. The Structure of Earth Crust of Territory of Tajikistan on Materials of Deep Seismic Researches; Donish: Dushanbe, Tajikistan, 1993; pp. 54-63. (In Russian)

34. Abdrakhmatov, K. Establishment of the Central Asia Seismic Risk Initiative (CASRI); ISTC Project No. KR 1176, 2009; Technical Report on the Work Performed from: 02.01.2006 to 04.30.2009; Institute of Seismology, National Academia of Sciences: Bishkek, Kyrgyzstan, 2009.

35. Mikhailova, N.; Mukambayev, A.; Aristova, I.; Kulakova, G.; Ullah, S.; Pilz, M.; Bindi, B. Central Asia earthquake catalogue from ancient time to 2009. Ann. Geophys. Italy 2015, 58, 102-111. [CrossRef]

36. Tsshoher, V.O. Seismic Zonation of the Urban Area and Antiseismic Engineering Building Codes; Soviet Academy of Science: Moscow, Russia, 1938; p. 103. (In Russian)

37. Nazarov, A.G.; Nechaev, V.A. Seismic Microzonation Map - The Administrative Area of Stalinabad; Academy Science, USSR: Dushanbe, Tajikistan, 1953; p. 15. (In Russian)

38. Kogan, L.A.; Nechaev, V.A.; Romanov, O.G. Seismic Microzonation in Tajikistan; Donish: Dushanbe, Tajikistan, 1974; p. 379. (In Russian)

39. Oripov, G.O. The Map of Seismic Microzonation of the Area of Dushanbe; Quarterly Report; GIINTIZ Institute: Dushanbe, Tajikistan, 1975; p. 150. (In Russian) 
40. Nakamura, Y.A. Method for Dynamic Characteristics Estimation of Subsurface Using Microtremor on the Ground Surface; Quarterly Report; Railway Technical Research Institute: Tokyo, Japan, 1989; Volume 30, pp. 25-33.

41. Wathelet, M. GEOPSY Geophysical Signal Database for Noise Array Processing. Software, LGIT, Grenoble. 2006. Available online: www.geopsy.org (accessed on 15 November 2019).

42. Nakamura, Y. What is the Nakamura's method? Seismol. Res. Lett. 2019, 90, 1437-1443. [CrossRef]

43. Bard, P.-Y. Microtremor measurements: A tool for site effect estimation. In The Effects of Surface Geology on Seismic Motion; Irikura, K., Kudo, K., Okada, H., Sasatami, T., Eds.; Balkema: Rotterdam, The Netherlands, 1999; pp. 1251-1279.

44. Bonnefoy-Claudet, S.; Köhler, A.; Cornou, C.; Wathelet, M.; Bard, P.-Y. Effects of Love waves on microtremor H/V ratio. Bull. Seism. Soc. Am. 2008, 98, 288-300. [CrossRef]

45. Field, E.H.; Jacob, K.H. A comparison and test of various site response estimation techniques, including three that are nonreference-site dependent. Bull. Seism. Soc. Am. 1995, 86, 991-1005.

46. Fäh, D.; Kind, F.; Giardini, D. A theoretical investigation of average H/V ratios. Geophys. J. Int. 2001, 145, 535-549. [CrossRef]

47. Bard, P.-Y.; SESAME-Team. Guidelines for the Implementation of the H/V Spectral Ratio Technique on Ambient Vibrations: Measurements, Processing, and Interpretations; SESAME European Research Project Report; European Commission-Research General Directorate Project No. EVG1-CT-2000-00026 SESAME; European Commission: Grenoble, France, 2004; p. 62. Available online: ftp: / /ftp.geo.uib.no/pub/seismo/software/sesame/user-guidelines/sesame-hv-user-guidelines.pdf (accessed on 15 November 2019).

48. Al-Heety, A.J.R.; Shanshal, Z.M. Integration of Seismic Refraction Tomography and Electrical Resistivity Tomography in Engineering Geophysics for Soil Characterization. Arab J. Geosci. 2016, 9, 731-741. [CrossRef]

49. Lankston, R.W. The seismic refraction method: A viable tool for mapping shallow targets into the 1990s. Geophysics 1989, 54, 1535-1542. [CrossRef]

50. Yilmaz, O.; Eser, M.; Berilgen, M. Seismic, Geotechnical, and Earthquake Engineering Site Characterization. In Proceedings of the 76th Annual International Meeting; SEG, Expanded Abstract. SEG: Tulsa, OK, USA, 2006; Volume 25, pp. 1401-1405.

51. Zhang, J.; Toksöz, M.N. Non-linear refraction travel time tomography. Geophysics 1998, 63, 1726-1737. [CrossRef]

52. Demanet, D. Tomographies 2D et 3D à partir de Mesures Géophysiques en Surface et en Forage. Unpublished. Ph.D. Thesis, Liége University, Liége, Belgium, 2000; p. 153.

53. Dines, K.A.; Lytle, R.J. Computerized geophysical tomography. Proc. IEEE 1979, 67, 1065-1073. [CrossRef]

54. Claprood, M. Spatially Averaged Coherency Spectrum (SPAC) Ambient Noise Array Method. In Shear Wave Velocity Measurement Guidelines for Canadian Seismic Site Characterization in Soil and Rock; Geological Survey of Canada, Open File 7078; Hunter, J.A., Crow, H.L., Eds.; Geological Survey of Canada: Ottawa, BC, Canada, 2012; pp. 94-102.

55. Horike, M. Inversion of phase velocity of long-period microtremors to the S-wave-velocity structure down to the basement in urbanized areas. J. Phys. Earth 1985, 33, 59-96. [CrossRef]

56. Ishida, H.; Nozawa, T.; Niwa, M. Estimation of deep surface structure based on phase velocities and spectral ratios of long period microtremors. In Proceedings of the 2nd International Symposium on the Effects of Surface Geology on Seismic Motion, Yokohama, Japan, 4 April 1998; Volume 2, pp. 697-704.

57. Satoh, T.; Kawase, H.; Shin'Ichi, M. Estimation of S-wave velocity structures in and around the Sendai Basin, Japan, using arrays records of microtremors. Bull. Seismol. Soc. Am. 2001, 91, 206-218. [CrossRef]

58. Yamanaka, H.; Takemura, M.; Ishida, H.; Niwa, M. Characteristics of long-period microtremors and their applicability in the exploration of deep sedimentary layers. Bull. Seism. Soc. Am. 1994, 84, 1831-1841.

59. Asten, M.W. On bias and noise in passive seismic data from finite circular array data processed using SPAC method. Geophysics 2006, 71, 153-162. [CrossRef]

60. Aki, K. Space and time spectra of stationary stochastic waves, with special reference to microtremors. Bull. Earthq. Res. Inst. 1957, $35,415-456$.

61. Aki, K. A note on the use of microseisms in determining the shallow structure of the Earth's crust. Geophysics 1965, 30, 665-666. [CrossRef]

62. Ohori, M.; Nobata, A.; Wakamatsu, K. A comparison of ESAC and FK methods of estimating phase velocity using arbitrarily shaped microtremor arrays. Bull. Seismol. Soc. Am. 2002, 92, 2323-2332. [CrossRef]

63. Okada, H. The Microtremor Survey Method. American Geophysical Monograph 12; American Geophysical Union: Washington, DC, USA, 2003; pp. 1-14.

64. Borcherdt, R.D. Effects of local geology on ground motion near San Francisco Bay. Bull. Seismol. Soc. Am. 1970, 60, $29-61$.

65. Rodríguez, V.H.; Midorikawa, S. Comparison of spectral ratio techniques for estimation of site effects using microtremor data and earthquake motions recorded at the surface and in boreholes. Earthq. Eng. Struct. Dynam. 2003, 32, 1691-1714. [CrossRef]

66. Bonilla, L.F.; Steidl, J.H.; Lindley, G.T.; Tumarkin, A.G.; Archuleta, R.J. Site amplification in the San Ferdinando Valley, California: Variability of site effect estimation using S-wave, coda, and H/V methods. Bull. Seism. Soc. Am. 1997, 87, 710-730.

67. Parolai, S.; Richwalski, S. The importance of converted waves in comparing H/V and RSM site response estimates. Bull. Seismol. Soc. Am. 2004, 94, 304-313. [CrossRef]

68. Wathelet, M.; Jean-Luc, C.; Cornou, C.; Di Giulio, G.; Guillier, B.; Ohrnberger, M.; Savvaidis, A. Geopsy: A User-Friendly Open-Source Tool Set for Ambient Vibration Processing. Seismol. Res. Lett. 2020, 91, 1878-1889. [CrossRef] 
69. Konno, K.; Ohmachi, T. Ground-motion characteristics estimated from spectral ratio between horizontal and vertical components of microtremor. Bull. Seismol. Soc. Am. 1998, 88, 228-241.

70. Guéguen, P.; Chatelain, J.L.; Guillier, B.; Yepes, H. An indication of the soil topmost layer response in Quito (Ecuador) using noise H/V spectral ratio. Earthq. Eng. Soil Dynam. 2000, 19, 127-133. [CrossRef]

71. Havenith, H.-B.; Jongmans, D.; Faccioli, E.; Abdrakhmatov, K.; Bard, P.-Y. Site Effect Analysis around the Seismically Induced Ananevo Rockslide, Kyrgyzstan. Bull. Seismol. Soc. Am. 2002, 92, 3190-3209. [CrossRef]

72. Wathelet, M. An improved neighborhood algorithm: Parameter conditions and dynamic scaling. Geophys. Res. Lett. 2008, 35, 1-5. [CrossRef] 